\title{
A POSSIBLE FĀȚIMID BACKGROUND TO THE BATTLE OF MANZIKERT
}

\author{
by Abbas HAMDANI
}

(Milwaukee)

The Battle of Manzikert ${ }^{1}$ in $463 / 1071$ is an important land-mark in history in so far as it resulted in two important processes-the gradual settlement of the Turks in Asia Minor (along with the Islamisation of the heart-lands of Byzantium), and the beginning of a Byzantine desire to open its territories to western European powers for the launching of the Crusades. The causes of the battle are equally important. First of all, there was the constant conflict between Byzantium and the central Muslim power, aggravated by the arrival of Turkish tribes and the rise of the Saljūqs in the eleventh century. Second, the Armenian territories played a significant role in providing a setting for this conflict. But one aspect of Manzikert which has never been emphasized, though not altogether neglected, is the active Fãtimid foreign policy connected with frustrating the rise of the Saljūqs in the East. It is this last aspect which I wish to isolate for discussion in the following pages, not so much to contribute new information as to furnish a re-interpretation indicating possible Fāțimid machinations behind the Battle of Manzikert. ${ }^{2}$

\section{Byzantium and the Central Muslim Power.}

Much has been written about the relations between Byzantium and the Arabs (beginning shortly before Islam and in Muslim history) down to the

1 The name is spelled Mantzikert or Manzikert in western sources; Manãzgard, Malāzgirt in Muslim sources.

2 A full bibliography at the end of this article is given only to illustrate the many-sided complexity of the subject. However, due to the limited scope of this article it has been used here only in a selective manner.

The references below are abbreviated as given in the bibliographical index. 
'Abbāsid period by scholars such as Brooks, ${ }^{3}$ Vasiliev, ${ }^{4}$ Wellhausen, ${ }^{5}$ Canard ${ }^{6}$ and Gibb. ${ }^{7}$ Canard ${ }^{8}$ has continued with a discussion of these relations in the Hamdānid period, while Laurent ${ }^{9}$ and Cahen $^{10}$ have given us the Turco-Byzantine picture. The Caucasian background has been provided by Toumanoff. ${ }^{11}$ A vast variety of sources-Islamic, Greek, Armenian and Syrian have been used by these writers. The story that emerges from their labors is too long and not immediately relevant. Yet a summary is given in the notes for convenient reference. ${ }^{12}$ There are certain salient features of their presentation, however,

\footnotetext{
3 Brooks: Asia Minor; Byz. -Arabs.

4 Vasiliev: Byz.-Arabes; Episodes.

5 Wellhausen: Kämpfe; Arab Kingdom.

6 Canard: Expeditions; 'A-cotê.'

7 Gibb: Relations.

8 Canard: Hamdanides; Hamdānids-E.I.

9 Laurent: Byz. et Turcs.

10 Cahen: Mantzikert; Turkey, among other titles mentioned in the index.

11 Toumanoff: Background.
}

12 The story begins with the M'uta campaign in 8/629 when Prophet Muhammad for the first time changed his hitherto friendly attitude towards Byzantium by mounting an expedition to meet the invading forces led by Heraclius. This was the prelude to the conquest of Mecca and the debut in Islam of Khālid b. Walid's career. Many Byzantine positions in Syria were taken in the last years of the Prophet's life. The wars of conquest in the time of Caliph 'Umar took away two of Byzantium's best provinces-Egypt and Syria. Mu'ãwiya, then as governor of Syria took Cyprus in 29/649. 'Abdullah and then 'Amr as governors of Egypt conquered Byzantine territory in North Africa namely the Pentapolis (Barqa) region and reached Carthage (Qayrawān). A Syro-Egyptian fleet engaged a Byzantine fleet of 500 ships under Constans II off the Lycian coast in $35 / 655$. After assuming the title of Caliph, Múa ãwiya sent under his son Yazid an expedition toward Constantinople in 48-49/668-669. With this the interesting legend of Abū Ayyūb al-Anșāin and his combat and burial near the walls of the city are connected. The year $52 / 672$ saw the conquest of Rhodes or Cyzique depending on the interpretation of the name "Arwād". At the end of Mu 'ãwiya's reign a seven year's campaign (54-60/674-680) is reported which could have been continuous border engagements, till events in Arabia suspended it for the time as soon as the Caliph 'Abdal-Malik raised his head from the involvement against the rebel Ibn Zubayr, he resumed in $73 / 692$ the struggle against Byzantium. Justinian II was defeted at Sebastapolis. Tyana in Cappadocia was taken in 89/707 at the beginning of Walid I's reign. Again during the period of the great Muslim conquests in the time of Walid I preparations for a campaign against Constantinople began in $95 / 713$, continued with the capture of Sardis and Pergamon and culminated in the siege of the eity in $98 / 716$ in the time of Caliph Sulaymān by his brother, Maslama. Although the internal condition of the Caliphate demanded Muslim withdrawal, many legends are woven round this campaign, namely the supposed entry of Maslama in Constantinople and the building of a mosque there. Hishām's time brewed with revolt and although he had resumed war with the Byzantines, no headway could be made. The Muslim lands were now engulfed in the sweeping 'Abbāsid revolution and Byzantium got its respite once again. 
The situation of Armenia is of special significance (cf. Toumanoff: Background, Grousset: Arménie; Charanis: Byz. Eleventh Cent.). It was the Persian recruting ground in its wars with Ancient Greece and Byzantine recruiting ground against later day Persia. Despite the Peace of Rhandia in 63 A.D. it remained the bone of contention between Byzantium and the Sāssānid Irān and later between Byzantium and Islam. Mu ‘âwiya's General Habib al-Fihri had occupied it in 24/644-5 but it was lost to the Muslims shortly after the death of the Caliph, when civil war broke out in Arabia. After the second 'Abbāsid Caliph Manșūr consolidated his position against the rebels in Hijāz, 'Iraq and Persia, Armenia again became the battleground between Byzantium and Islam. The ruined border fortresses of Melitene and Massisah were restored and even Baku is reported to have been reached. During the time of his successor Mahdi, the latter's son Hārūn led an expedition against Constantinople in 166/782 and reaching the Bosphorus, a treaty was concluded by which Queen Irene on behalf of her minor son Constantine VI agreed to pay a large semi-annual tribute. Hārūn received from his father the title of ar-Rashid as a result of his conduct of this campaign. On Nicephorus I's repudiation of the treaty, Hārūn, now as Caliph sent an expedition that resulted in the capture of Tyana and Heraclea, and the re-imposition of the tribute. Hārūn's exchange of friendly embassies with Charlemagne was based on their common hostility to both Umayyad Spain and Byzantium. Hārūn's son Ma'mūn personally commanded a campaign against Theophilus (82942) but died enroute at Tarsus in 218/833. The next Caliph Mu tașim continued the expedition and succeeded in taking Amorium in 225/839. From his time, the Caliphate entered its Sämarra phase dominated by the Turkish Amîrs al-Umarä', too much involved in its internal affairs to be able to continue its hostilities against Byzantium.

However, in another area of Byzantine influence - the Mediterranean, the Aghlabid dynasty (184-296/800-909) of North Africa took up on behalf of the 'Abbāsid Caliphate, a struggle that resulted in their occupation of Sicily. The reduction of this important Byzantine island began in 217/827 in the time of the third Aghlabid ruler Ziyädat Allah I and was completed in $287 / 900$ by the capture of Palermo and Reggio in the time of the ninth Aghlabid ruler Ibrāhim II. In the meantime Malta was acquired in 255/868. (cf. Talbi: Aghlabides; Marcais: AghlabidsE. I. 2)

The 'Abbāsid Caliphate had returned to Baghdād from Sāmarra in $279 / 892$, but was still in the grip of the Amirs al-Umara. In the meantime many petty dynasties in the West as well as in the East had become autonomous. What is more, rival Caliphate of the Fãtimids had been instituted in North Africa in $297 / 909$ with a vigorous mission and an expanding empire. At the centre the Būyids, a Persian dynasty, although of Shi' ite persuation, had replaced the Turkish Amirs al-Umara and dominated the affairs of the Caliphs at Baghdad. (Kabir: Buw. Dyn.; Cahen: Buwayhids-E.I.2)

This was a period of utter weakness of the Central Caliphate but coincided with a great revival and resurgence of Byzantine authority under its Macedonian Dynasty. The brunt of the Byzantine attack was born by the Hamdānids (293-394/905-1004) of Syria and the Fãtimids of North Africa and Egypt. Aleppo in the hands of the Hamdannid ruler Sayfad-Dawla (333356/945-967) was the base of almost yearly campaign in Asia Minor. However, Nicephorus Phocas, in 350/961 a Byzantine General, succeeded in taking Aleppo and punishing the town with a massacre. He retired within nine days. On his becoming Emperor two years later many territories in Cilicia were recovered and Cyprus reconquered. In 358/969, the last year of his reign,the important religious center of Antioch was taken(about the same time as the Fāțimid 
that could be noted here. The Muslim war against Byzantium was continuous and was only interrupted in times of civil war, as for example during the wars of Ridda, the war between 'Alī and Mu'āwiya, the war of 'Abd Allah b. Zubayr against Yazīd, Marwān and 'Abd al-Malik, the period of the changeover from the Umayyad to "Abbāsid rule and the involvement of the 'Abbāsid Caliphate with provincial and central Amīrs. Second, despite the war, the rulers of Byzantium and Islam had numerous occasions to exchange gifts and courtesies and to promote commercial pursuits. ${ }^{13}$ Third, both the Muslim ghāzis and the Byzantine akrites believed in the necessity of a holy war, a doctrine which was generated by centuries of incessant conflict, making it difficult for any Muslim ruler to declare alliance or friendship with Byzantium. One could manage, however, with a truce. Moreover, there was never a wholesale crusade or jihād but fighting for border fortresses and booty. Such a situation was not desperate. It became so only in the eleventh, when the great flood of Turkish tribes began to spill over Asia Minor. A similar movement of the Arab bedouin tribes (the Hilali migration) was sweeping over North Africa at about the same time, and we shall see the connection between the two presently.

\section{The Turkish tribes and the Rise of the Saljüqs:}

Turks had played an important part in Middle Eastern politics before the advent of the Saljūqs ${ }^{14}$ and even constituted independant dynasties such as the Ikḩsḩidids. The Arab scholar Jāhịiz devoted a Risāla to their praise. ${ }^{15}$ But with them we are not concerned here. The advent of the Turkish tribes in the eleventh century was epoch-making and the subject is discussed at

occupation of Egypt) and it remained in Byzantine hands until 477/1084. Aleppo under Sa'd ad-Dawla had to sign a humiliating treaty. Emperor John Tzimisces (969-76) may have envisaged the conquest of Jerusalem but was deterred by the Fãtimid entry in Syria and the Ḥamdānid allegiance to them (see Paul walker: The so-called Crusade of John Tzimisces, paper given at the 6th Conference on Medieval Studies, Western Michigan University, may, 1971). Basil II (976-1025) campaigned in Syria against the Fātimids but had to sign a ten-year truce with them in $388 / 998$ and that ushered in an entirely new relationship of peaceful co-existence between the two empires that endured for more than 70 years (with interruptions and provocations of course!) till the Battle of Manzikert.

13 Gibbs: Relations, pp. 55-60.

14 Aydın Sayıı: Turks in the Middle East before the Saljuqs, J. A. O. S., 1943.

15 Al-Jāhịiz: Risāla fĩ manāqib at-Turk va 'ãmmat jund al-Khiläfa in Tria Opuscula, ed. Van Vloten, Leiden, 1903. Cf. Bosworth: The Ghaznawids, pp. 206, 209, where other writers like Ibn Hawqal and Ibn Hassūl are also cited. 
length by Cahen in two articles, ${ }^{16}$ also previously by Laurent ${ }^{17}$ and Mukrimin Halil. ${ }^{18}$ The tribes mentioned are: the Qinīq, from whom the Saljūqs were derived (on the authority of Maḥmūd Kāshgharī and the Malik-nāma); the Döger in the Kurdish region, to whom belonged the later day Artüqids (on the authority of Vardan and Jazari); the salghür, who gave their name to a 12th century dynasty in Fārs, but arrived early alongside with the Saljūqs (on the authority of the 16th century Shīrāz-näma); the Ivãlī in the Adberbaijan-Armenian region who figure at the end of the 12th century when under the name of Yärüqĩ they were transplanted near Aleppo by the Zangî (on the authority of I. Atb̧, Rāwandî, 'Imād ad-Dīn and Nasawī, but Cahen thinks they came early in the eleventh century); the Avshär, who were a significant tribe in Khūzistān region in the late 12th century (on the authority of Köprülü's article Avşar in the Turkish Encycl. of Islam, but Cahen thinks they arrived earlier).

More relevant to our story are the tribes that entered Anatolia. YãzijīOghlū (ed. Houtsma) repeatedly mentions the Qaï, the Bāyāt, the Bayundūr and the Sālür (Salghūr) but Cahen eliminates the information on the ground that they figured much later and that Yãziji mentioned them as a matter of style since these peoples were the four pillars of Saljūq power. We are not concerned here with the Aghatsheri (mentioned by Bar Habraeus, Ibn Bỉbī, Ibn Shaddād etc.) which belong to a much later Mongol period.

The one tribe that figured early in Anatolia, that remained in Anatolia (settled later in the northwest region) and that played a part in the events prior to the Battle of Manzikert was called variously the Nävūki, Yãvuki, Närū$k i$ or $B \bar{a} d u k i \bar{i}$ (because in the Arabic letter " $n$ " the change of dots would result in " $y$ ", or " $b$ "; whereas " $r$ " and " $v$ " could also be confused). Cahen has pointed out, however, that the name could come from the Khwarazmian Nav-qi (Tribus, p. 186). The Saljūqs, it is well known, had settled in Kvwarazmian territory before their occupation of Khurāsān, and that Chaghrī and Tughril had married a Khwwarazmian lady. (Same) Tugbril's sister Jawhar Kḩātūn was married to Arisighiji ${ }^{19}$ (or Erisgen) who was the muqaddam (leader) of the Nāvukĩ. Shortly after the Battle of Manzikert, the leader of the Nāvukĩ was Atsīz b. Uvaq, again Kbywarazmian. ${ }^{20}$

\footnotetext{
16. Cahen: Penetration Turque (1948); and Tribus (1950).

17. Laurent: Byz. et Turcs (1914).

18 Mukrimin: Turkiye Tarihi (1934).

$19 \mathrm{He}$ is Chrysosculos in Bryennins Commentari 32 and 117.

20 Sibț: Mir'āt in Amedroz ed. of I. Qal.: Dhayl pp. 98-99.
} 
Bayhaqi (d. 470/1077), who was contemporary to the early migration of Turks westwards, in his $T a^{2}$ rikkh $M a s^{e} \bar{u} d \bar{i}^{21}$ has a chapter on Kbowarazm where he repeatedly talks of two Turkish families or tribes who had come to that area, viz. Saljūqiyān and Yināliyān. It is generally accepted that Ibrāhīm Yināl was a half-brother of Tughril and therefore the separate identity of the Yinālî is ignored. But it appears that the Yinālĩ were just as much a separate group as the Nāvukī, connected by marriage with the Saljūqus, and like the latter entered Anatolia and claimed to be the Mawālî Amīr al-Mu'minin (the clients of the Caliph). ${ }^{22}$ They are also referred to as Yaghmūriān, and Qiziliyān ${ }^{23}$. Cahen ${ }^{24}$ states that Ibrāhỉm's mother had later married Tugh̆ril's father Mikā'îl or that Mikā'ỉl's widow had married Ibrāhîm's father. Thus Tughril and Ibrāhīm were half-brothers. This is in keeping with most of the sources. However, much confusion has arisen on the name Yüsuf. (i) According to some he is the father of Ibrāhīm. ${ }^{25}$ (ii) According to others he is the fourth son of Saljū $q^{26}$ (the other shree being Arslan=Isrā'īl, Mūsa and Mikä’il) and (iii) sill according to others he is Saljūq's grandson Yūsuf b. Mūsa. ${ }^{27}$ (iv) Yūsuf (or Yūnus) is also the father of Arĩsighỉ mentioned above, according to one version. ${ }^{28}$ It is quite possible that there were several individuals called Yūsuf, and that this is the cause of confusion among our sources. Synthesising the genealogy, ${ }^{29}$ Cahen arrives at: Ibrāhīm b. Yūsuf Yināl b. Mūsa b. Seljūq, which would place him a generation below Tugbril and would not in that case make him his half brother. The purpose in going into this discussion here has been to maintain that Yināliya were a separate tribal group. ${ }^{30}$ Two factors bear this out: Bayhaqi's referring to them as separate from Saljūqs and the word Yīnāl applied to both Ibrāhīm and his father Yūsuf, as a group or tribal designation. We will notice later Ibrāhīm's initial support to Tugḩril and later defiance of him, in collusion with the Fãțimids.

21 Ed. by Sa'id Nafisĩ, Teheran, 1940-53, Vol. III, pp. 829, 830, 837.

22 Ibid, pp. 582, 863.

23 Idem.

24 Cahen: Malik-Nameh, p. 58.

25 I. J. Muntaẓam, VIII, 114

26. Ta'rikh Āl Saljūq in Cahen: Malik-nämeh, p. 58 .

27 By virtue of Cahen's identification of this Yüsuf b. Müsa (mentioned in Rãwandi) as Yũsuf Yināl.

28 Zahïr ad-Din Nishāpūrī group of historians, according to Cahen: Malik-Nämeh, p. 58.

29 Cahen: ibid.

30 Genealogical reconstructions: (See Chart at the end of the notes). 
Many of these tribes that flooded Asia Minor from the east belonged to the Oghuz Turkic confederation, who are called by the Arabic sources Ghuzz. However, there were other tribes of the Ghuzz that had descended on Byzantium from the north and on the Balkan frontiers since 1065. These were known to Byzantine historians ${ }^{31}$ as Uzes. Charanis ${ }^{32}$ says, "The Uzes are merely the Oghuz in Byzantine form, but the distinction is useful in separating those who crossed the Russian steppe from those who crossed the Persian plateau." The Ghuzz, however, were not the first Turkish tribes that Byzantium had to cope with. Since the ninth century thousands of Pechenegs (or Patzinaks) ${ }^{33}$ and Kumans had crossed the Danube into Byzantine territory and it took much tact and diplomacy by that state to keep them in check.

A distinction has been made by Cahen $^{34}$ between the autonomous Turkish tribes and those under the control of the Saljūq sultāns - the former were predatory, the latter disciplined regular army; the former had plunder, booty and ransom in mind, the latter pursued political ends. But the distinction is very thin. How can we classify Ibrāhïm Yināl's raids in Armenia of $440 / 1048$ as predatory and Tughril's campaign of $446 / 1054$ as regular ?35 Again how can we make a distinction between the activities of Arīsĩghỉ, leader of the Navūkĩya and those of Sultān Alp Arslān's protégé Afshīn, both prior to the Battle of Manzikert ? $^{36}$ Booty and ransom- money formed an important item in the Sultān's budget and was used for political purposes. But the more important factor is that of migration. The Middle East was overflowing with newly arrived Turkish tribes, who may have been nomadic to begin with but were definitely in search of a new home and not just grazing grounds for their animals. Their rapaciousness was only a passing phase. The ethnic-religious opposition of both the Fātimid and the Byzantine states emanated not from fear of the Turks as such, but from the fear of the settlement of this new element. The eagerness of the 'Abbāsid invitation to the Saljūqs was not so

31 eg. Cedrenus - Skylitzes, Hist. II, 654.

32 Charanis: Byz-Eleventh Cent., p. 185, note 6.

33 See Valilievsky: Patzinaks and McCartney: Pechenegs pp. 342-355 and Charanis, op. cit. 34 Cahen: Manzikert, p. 621.

35 I. Ath: Kāmil, IX, p. 546; I. J.: Muntaz̧am, VIII, p. 137, 160.

36 Sibṭ: Mir'ät, in Amedroz'sedition ofI. Qal.: Dhayl, pp.100-101. (about Arisighīi and Afshin). See Köymen: Askeri Teşlkilati for the clear distinction made between the Turkoman forces of the earlier period and the regular army of Ghuläms recruited later when the Saljūq Empire had been established; particularly the invariable employment of the Turkoman irregulars against non-Muslim countries (p. 36). 
much a result of the love of orthodoxy as a result of the desperation stemming from their conflict with the Fātimids.

'Abbäsid invitation to the Saljūqs.

The early history of the Saljūqs-their tribal origin and settlement in Khwwārazīm, conversion to Islām, Šāmānid and Qārākhānid service, hostility to the Ghaznavids leading to the Battle of Dandanaqaan with them in 431/ 1040 has been related by Cahen (in his article Malik-Nameh and book Turkey) where four different traditions in muslim sources are examined: (i) the early Persian historians of the Ghaznavids, mainly Gardizĩ (ca. 441/1050) and Bayhaqĩ (d. 470/1077); (ii) the Baghdādi historians Ibn al-Jawzī (d. 597/1200) and Sibt b. al-Jawzi (d. 654/1256) (iii) the Persian work Malik-Nameh (lost) which was the basis of 'Imād ad-Din's (d. 560/1164) account (although not acknowledged) which in turn was the basis of Bundari's abridgement (with acknowledgment). Malik-Nameh was followed in the 7th/13th century work Zubdat at-Tawärïkh which in turn was followed by Ibn al-Athïr (d. 631/1233) without acknowledgment. The Malik-Nameh tradition is also embodied in the works of Bar Habraeus (7th/13th cent.) and Mirkbwand (d. 904/1498) (iv) the Saljüqnäma of Zahir ad-Dīn Nishäpürī (6th/12th century) which follows a tradition independent of Malik-nämeh and is followed by Räwandī (end of the 6th/12th century). Cahen's summaries have been succinctly stated in English by Kouymjian in his article (1969) on Mixit'ar of Ani. The details of these works will be found in the bibliographical index attached. Restatement of this early Saljūq history is not necessary as it is only remotely relevant here.

We pass on, then, to the 'Abbāsid interest in inviting the Saljūqs. Since 336/946 the Abbäsid Caliphate had come under the tutelage of the Buwayhid Amīrs. The Sunni Caliphate had been incongruously adjusted to a Twelver Shỉ' political authority but together they shared a common rivalry with the new Shỉĩ Ismā'ili dynasty of North Africa-the Fāțimids. However, the increasing power of the Fãtimids (for in the first half of the 5th/11th century they also controlled Egypt, Syria and the countries bordering on the Red Sea, and had their Kbuța read at Mecca and Medina) and the weakening of the Buwayhids by internal dissensions and military revolts, had created for the "Abbāsid Caliphs a danger as well as an opportunity. The opportunity increased with the rise of such stalwarts as Mahmūd of Ghazna and later Tughril Beg in the East; and the danger decreased because of the chaos in which Egypt had been plunged by an eccentric Caliph al-Ḥākim (386-411/996-1201). 
Two measures that the 'Abbāsid Caliph al-Qãdir (381-422/991-1031) adopted were of far-reaching significance-the issuance of a manifesto against the Fātimid origin of the Fātimid Caliphs in $402 / 1011^{37}$ which heralded an ever-growing anti-Fāțimid campaign, and the commissioning of the Qãdi Mãwardĩ to write his famous book on Sunnî political theory al-Ahkäm asSultänīya ${ }^{38}$ which justified the legitimacy of the 'Abbāsid Caliphate by fending off the objections that could be made to the many irregularities in the institution. The same Māwardī (often referred to as Aqụa'l-Quḍāt) was destined to be the next Caliph's (Qā’im) ambassador to Tughril Beg. It must be remembered that in the history of 'Abbāsid-Fātimid conflict, the Qāḍis played as important a role in the service of the 'Abbāsid Caliphate and orthodoxy as the $D \bar{a}^{e}$ is played in the service of the Fãtimid Caliphate and heresy. Only two other examples in the immediate context need be mentioned here. In the time of the Caliph Qā'im we know of the high position and missions of the Qāọi Dāmighānī, and of a rabble-rousing Qāḍi Ibn Musḩtarỉ in the court of the penultimate Būyid Amīr Abū Kālijjār at Shīrāz who almost chased away the Fāṭimid dāẽ Mu'ayyad from there. ${ }^{39}$

The Caliph Qā'im (422-467/1031-1075) was even more energetic than his predecessor. He had a young advisor Ibn al-Muslima ${ }^{40}$ from the very beginning of his career. The contemporary Fāțimid agent at Shīrāz, Mu'ayyad ${ }^{41}$ states that Ibn al-Muslima arrived at Ahwāz en route to Shīrāz, threatening to oust him by force from the Büyid court, but that he left on his own in 429/ 1038. He also states that Ibn al-Muslima had committed many atrocities against the Shỉ'i places of worship. He further informs us that Ibn al-Muslima was instigating the revolt of $\mathrm{Mu}^{\mathrm{C}} \mathrm{izz}$ b. Bādīs, the Zïrid governor of Qayrawān against the Fātimids of Cairo. Later in $437 / 1045$, the penultimate Būyid Sulțān's wazīr Ibn Fasānjas intrigued to get 'Amīd ad-Dawla deposed by the 'Abbāsid Caliph and Ibn al-Muslima appointed in his place as the Ra'is arRu'asā.42 However, Ibn Fasānjas was executed by Abū Kālījār two years

37 I. Ath., Kämil, IX, 236 and I. J.: Muntazām, VII, 281-2. The full text of the manifesto as given in Abu'l-Fidā is translated in Manour's Polemics on the origin of the Fäțimi Caliphs, London, 1934, p. 25.

38 See Gibb's article: Al-Mäwardī's Theory of the Caliphate in his Studies on the Civilisation of Islam, pp. 152-53.

39 Mu'ayyad: Sïra, pp. 9-10.

40 I. J.: Muntazam, pp. 200-1 gives the date of his birth as $397 / 1006$.

41 Mu'ayyad: Sïra, pp. 56-57.

42 I. Ath. Kämil, IX. 530. 
later. ${ }^{43}$ Ibn al-Muslima later succeeded in running the Büyid commander Basāsīrī out of Baghdad. He was the chief promoter of 'Abbāsid-Saljūq solidarity.

The Saljūqs and the Yināliya left Central Asia in 426/1035 and arrived in Khurāsān claiming to be the clients of the Commander of the Faithful (Mawālī Amīr al-Mu’min.n). ${ }^{44}$ In 428/1037, Chaghr. took Marw, Ibrāhīm Yĩnal and Tughril occupied Nishapur in 429/1038. Soon after that an 'Abbāsid envoy, the Qāḍi Sa ĩd arrived at Nishāpur ostensibly to protest against the ravages committed by the Turkoman troops ${ }^{45}$ but in fact to begin negotiations For Tughril's takeover from the Büyids. Tughril assumed the title of as-Sulțān al-Mu'azzam in 429/1038 ${ }^{46}$ and was prayed for in Bayhaq as a Sulțān. ${ }^{47}$ In $431 / 1040$, the Battle of Dandanaqān was fought against the Ghaznawid Mas' ūd, who was defeated and had to abandon Kḥurāsān finally to the Saljūqs. ${ }^{48}$ In 434/1042 Ibrāhīm Yināl entered Rayy followed there by Tugbrili. ${ }^{49}$ Tughril received the Caliphal envoy, the famous Qãḍi Māwardi ${ }^{50}$ in the same year. The professed purpose of the mission was to seek correction of the activities of one 'Alī b. Muhammed b. Habỉb. Ibn al-Jawzī informs us that the next year the Qāḍi revisited Tughril who went out four parasangs to reveive him. ${ }^{51}$ The repeated visit of the Qãdi and the welcome given him by Tughril show that some negotiations were in progress. Probably these resulted in the Caliphal confirmation of Tugbril as a Sultān, for we are informed by Miles ${ }^{52}$ of a dīnār from Rayy dated 438/1046-7 which bears the name "as-Sulțān almueazzam Shāhinsḩāh Tugḩril Beg Abū Țālib." Only a year earlier in 437/ 1045-6 had Tughril received from the Caliph permission to strike coins. ${ }^{53}$

Again the purposes of the mission of Qãḍī Mãwardī can be inferred from the events that soon followed, namely the stepping up of pressure on.

\footnotetext{
43 Ibid., p. 542.

44 Bayhaqi, Ta'rikh, 582, 863, Juzjani, Tabaqät, p. 120.

45 Bayhaqī, Ta'rikh, p. 692. Cf. Cahen: Malik-Nāmeh, p. 62.

46 Cahen: Malik-Nameh, p. 62; Bosworth: Ghaznavids, p. 267; Akhbär, trans. 6-7.

47 I. Funduq: Bayhaq, 274; Cahen: idem.

48 Attested by all the chronicles; see the Malik-nameh version in I. Aths: Kämil, IX, 483; Mirkbwand: Rawḍ, 18-35.

49 I. J. Muntaẓam VIII, p. 113.

50 Idem.

51 Ibid., 116; I. Ath., Kāmil, IX; Bundarī, Zubda, p. 27; Bar Habraeus, Chronography, p. 201. Cf. Makdisi, Ibn 'Aqïl, p. 81.

52 Miles, G. C.: The Numismatic History of Rayy, New York, 1938.

53 Rāwandi (following the Nishãpuri School), Räha, p. 105 (trans. p. 104). This is considered by Iqbal, the editor and translator of the Räha, as too early a date. He suggests $447 / 1055$.
} 
Byzantium and the encirclement of the Fātimids. The king of Vaspurkan had ceded his territory to the Byzantine Emperor in 412/1021. Between 431/ 1039 to $435 / 1043$ Byzantium had annexed the Armenian kingdom of Ani. But the very devastating raid of Ibrāhīm Yỉnal on Armenia in 440/1048 ${ }^{54}$ had led the Emperor Constantine Monomachos to join his forces with those of the Iberian prince Liparites and the Byzantine governors of Vaspurkan and Mesopotamia who now massed a large army to meet the new Turkoman danger. ${ }^{55}$ However, this army was defeated and Liparites taken prisoner. The Emperor was obliged to send a mission to Tughril (led by the former's secretary, Giorgios Drosos, in 442/1050) which demanded and got the release of Liparites, and which promised to have the Khutba read in the mosque of Constantinople in the name of the Sulțān. ${ }^{56}$ Laurent doubts that it was ever done. ${ }^{57}$ The Marwānid prince of Diyār-Bekir, Nașr ad-Dawla, who vas in the Byzantine sphere of influence did read the Kbuța for Tughril ${ }^{58}$ and so did the Rawwādid prince Wahsūdān at Tabrīz and the Shāddādid prince Abu'l-Aswār at Ganja. ${ }^{59}$

Let us turn to North Africa and Egypt. The Zïrī Amīr of Ifrīiiya, Mu'izz b. Bādis (r. 496-453 /1015-1061) who was officially under Fāțimid protection, began to show signs of independence, with some encouragement from Baghdad. We have precious information on this from Maqrizzi who is the most useful historian for the Fățimid period. Although he wrote in the fifteenth century, he utilised contemporary Fātimid sources such as the historians Musabbihịi (d. 420/1029) and Qudāeĩ (d. after 461/1069) whose works have survived only in small sections, and Ibn aṣ-Ṣayrafĩ (d. $542 / 1147)$ whose works are separately available to us. Jamāl ad-Dīn Shayyāl very recently (1967) published Maqrizì's $I t t i{ }^{e} \bar{a} z$ from a complete manuscript of it (the only one known) preserved in the Ahmad III Library at the Topkapu Serai in Istanbül (no. 3031), but before the second part of it could be published he died. The information relevant for us would have been in this part. However, fortunately, H. R. Idris extracted from this part all the passages concerning the Fãțimid-Zïrid

54 I. J. Muntaz̧am, p. 137, I. Ath: Kämil IX. p. 546.

55 Cahen: Penetration Turque, p. 15 on the authority of Arisdaguès; Histoire, pp. 74-85, Attaligtes: Historia, pp. 44-45; Cedrenus-Skylitres: Hist., pp. 575-580; Mathew: Chronique, pp. 83-88 and Brosset Georgie, I, 323.

56 See Dölger: Regesten, II, p. 9 (no. 898) and the documentation in it.

57 Byzantion II, 109.

58 I. Ath: Kämil IX, p. 599.

59 Ibid., p. 598. 
relationship and published them in Arabica, vol. XI (1964). It is on this and with corroboration from Ibn 'Idhārī, that the following information is based.

Returning to the Zīrī Amĩr of Ifrĩqiya, Mưizz b. Bādis, we know that he received an ambassador from the 'Abbāsid Caliph Qä'im in $433 / 1041{ }^{60} \mathrm{Hav}$ ing received the robes of honor from Baghdād via Constantinople he had the Khuțba for the 'Abbāsid Caliph read throughout his realm and had the Khuțba of the Fātimids discontinued. ${ }^{61} \mathrm{Mu}^{e} \mathrm{izz}$ introduced a new currency in the Maghrib in 441/1049 and insisted upon black as a color of ceremonial dress (which was the color of the 'Abbāsid court) in 443/1051. The Amīr of Barqa (Cyrenaica) Jabara b. Mukb̧tār al-'Arabỉ declared for Mu'izz and read the 'Abbāsid Kbuțba also in $443 / 1051 .^{62} \mathrm{Mu}$ 'izz became curt in his correspondence with the Fāțimid Wazīr Yãzūrĩ and disrespectful in addressing the Fãțimid Caliph Mustansir - this being an important factor in the final rupture of Zỉrīd-Fāțimid relations, according to our historians. ${ }^{63}$

In the same year Mueizz asked Bagḩād for official investiture. Caliph Qā'im's envoy Abū Ghālib asḩ-Shirāzĩ was sent with an 'Abbāsid robe of honor, a black standard and gifts. The envoy arrived at Constantinople seeking permission to pass through to Qayrawān. But the Emperor Constantine was treaty-bound with the Fãtimids, and on request from Cairo, he re-routed the Baghdād embassy via Cairo. In Cairo, the envoy was humiliated and paraded on a camel; the papers of investiture, presents and the black standard were burned in the Bayn al-Qasrayn. Tughril Beg in the meantime had personally appeared at Constantinople asking permission to march across the Byzantine territory to Egypt, but was not allowed to do so. The 'Abbāsid envoy was returned to Constantinople. ${ }^{64}$

We have brought the narrative down to the year $443 / 1051$. To Maqrizĩ we owe the unique information about Tughril's presence near Constantinople in this year, probably taking advantage of the treaty made with the Emperor in the previous year (when Liparites was released). An interesting fact that emerges is the tactics of creating dissension between the Fāțimids and Byzantium in order to spoil a good relationship that had existed throughout the early part of the eleventh century. With the relationship contaminated, it

60 I. 'Idhārĩ: Bayān, p. 275.

61 Maqrīzi: $\quad I t i^{\complement} \bar{a} z$, Idris: Glances, p. 302.

62 I. 'Idhārī: Bayân, pp. 277-78, 288.

63 I. Șayrafĩ: Ishära, pp. 40-45 and Maqrizi: Itti ${ }^{~}{ }_{a} z$ (in Idris: Glances), 303.

64 Maqrizi: Itti ãz (in Idris: Glances 303 ; I. Muy, Akhbār, p. 5. 
was easier to proceed against both. We will notice similar tactics later in Sulțān Alp Arslān's occupation of Aleppo, before Manzikert.

The Fãțimid reaction was twofold: (i) to punish North Africa and the Zirids with the Hilālian invasion, whose main wave came in 443/1051 and (ii) to mount a campaign against Tughril Beg and Bagḩdād that resulted in Ibrāhim Yināl's defiance of Tugbril in 448/1057 and the occupation of Baghdad by Basāsīrī in 450/1058. But more about this later, which may explain a similar Fāțimid reaction to Sultān Alp Arslān's proposed march on Egypt, before the Battle of Manzikert.

We know that Tughril was awarded the title of "Rukn ad-Din" by the 'Abbāsid Caliph in 443/1051, after he received the treasures unearthed by Tugbril at Ișfahān on its conquest. ${ }^{65}$ The coins of Nishāpūr of this year bear this title. ${ }^{66} \mathrm{He}$ also received later, on his entry into Baghdād, the title "King of the East and the West", ${ }^{67}$ but the import of this title had already been in evidence much before. He was already the King of the East, and was encouraged by the 'Abbāsid Caliph to become also the King of the West (by occupying the territories of the Byzantine and the Fãtimid States). Probably this was the understanding arrived at in Qãḍi Māwardī's embassies to Tugbril as early as $434 / 1042$ and $435 / 1063$.

We must interrupt the narrative here, to examine the situation in the west.

Fäțimid-Byzantine relations.

Qãḍi'n-Nu'mān (d. 363/974) ${ }^{68}$ served the first four Fāțimid Caliphs, in North Africa and Egypt and rose to be the Chief Qãdī as well as a leader in the Ismāeili religious organization, the Da'wa. He is the author of the chief Fãtimid law-book $\mathrm{Da}^{\mathrm{e}} \bar{a}^{3} \mathrm{im}$ al-Islam. He also wrote the history of the establishment of the Fātimid Caliphate called Kitāb Iftitāhad-Daiwa (c. in 346/957) ${ }^{69}$ which contains some information on Fāțimid-Byzantine contacts. This source has been extensively utilised in Talbi's L'Emirat Aghlabide. Nu'mān's other

65 I. Ath: Kämil, IX, 397-8 and Bar Habraeus: Chronography, p. 206.

66 Miles, op. cit, p. 198.

67 I. J. Muntaẓam, VIII, 233, I. Ath: Kämil, p. 634 (under year 446 H.). Cf. Cahen: Turkey, p. 24.

68 See the bibliography of Isma 'ili works by Ivanow entitled Isma'ili Literature, Teheran, 1963, pp. 32-33.

69 It has recently been published at Beirut, but I have not seen it. However, I have the MS of the Hamdani collection. 
work Al-Majälis wa'l-Musāyarāt (Séances) $^{70}$ also contain an account of a Byzantine embassy at the Fātimid Court, which has been utilized by Stern (See index). A contemporary of Qāḍi'n-Nứmān, the poet Ibn Hānī (d. 362/ 973) sang the praises of the Fãțimid Caliph Mueizz, particularly his exploits against Rūm. Some of the poems from his Dĩwän have been used by Canard: L'Imperialisme and translated by Dewhurst (see index). And their contemporary Ustādh Jawdhar, secretary-treasurer of the Fãțimid Caliphs in his Sïra gives some information relevant to our subject (See index). Besides these Ismāîilī sources, the works of two Sunnĩ Qãḍis of Fāțimid Egypt, of the 5th/ 11th century, are of great relevance. One is al-Qādī ar-Rashỉd Ibn Zubayr whose Dhakhä'ir (see index) contains information on embassies exchanged between the Fãțimids and Byzantium, and the other is the Qāḍi al-Quḍāẽ, a historian and a sort of Kātib sirr (confidential secretary) of the Fāțimid Caliph Mustansir. His work 'Uyün al-Ma ärif (see index) has not been directly consulted, as its ms. in Cairo was not available to me. although Quḍāẽ is a key figure in this study.

For confirmation of information on Fātimid history of North Africa we have the geogropher al-Bakrī (d. 487/1094), and the historians Ibn 'Idbārī and Ibn Khaldūn (d. 809/1406). On the Fāțimid history of Egypt we have Ibn aṣ-Ṣayrafĩ (d. 521/1127), Ibn Zāfir (d. 613/1216), Ibn Muyassar (d. $677 / 1278$ ) and Bar Habreaus (events to 685/1286) (see index for their works).

There are also two historians of later times, Maqrīĩ (d. 845/1441) and the Da ĩ Idrīs 'Imād ad-Din (d. 872/1467), the former Sunnĩ and the latter Ismāiliz. Both are of immense importance, for they draw on detailed information given by earlier writers contemporary to the events, some of whose works have not survived.

There is a long list of the historians of Egypt, prominent among them being Ibn Taghribīrdi, Dawādārī, Ibn Qalqashandĩ and Dhahabĩ, who usually are useful for corroborating the evidence of earlier writers.

On Byzantine embassies, a basic reference-work is Dölger's Regesten (see index), full of information on treaties, truces, envoys, exchanges of gifts, ransoms, tributes etc. with documentation from original sources, Muslim and Byzantine, and from basic modern studies.

We have four general histories of the Fāțimid period, by Wustenfeld, Lane-Poole, O'Leary and Zahid Ali. Of these only the last one has used Fātimid-Ismāîli sources, but as his work is in Urdu it is little used. (See index for the titles). 
Byzantium had every reason to look upon the establishment of the Fãtimid Caliphate in North Africa in 297/909 with favor, for it opposed the 'Abbāsid Caliphate and had just defeated the Aghlabids of Qayrawān who had caused the Byzantine State much grief by their occupation of Sicily and other Mediterranean islands. Byzantine hopes were frustrated, however, because the Fātimids insisted on retaining their Mediterranean heritage from the Aghlabids. But in so far as they could divert the attack of the eastern Caliphate, their friendship was to be hoped for and to this end Byzantine policy was directed. Not always did the Fãtimids oblige, for they were keen on presenting an image of Islamic leadership untarnished by a friendship with this non-muslim power.

In the time of the Fātimid Mahdī, the Sicilian Muslim governor Ibn Quhrab tried to separate Sicily from North African rule by reading the Khutba for the "Abbäsid Caliph. However his rebellion was crushed and Sicily was re-secured in 304/916. At this time the Byzantine Emperor Constantine VII agreed to pay an annual tribute of 22,000 gold pieces to the new Fãțimid governor of Sicily, ${ }^{71}$ probably to purchase peace for the Italian coast harassed by the new Fãtimid navy with Sicily as its base. At the same time in 305/917 Byzantium sent an embassy to the "Abbāsid Caliph Muqtadir with gifts. ${ }^{72}$

The King of Bulgars sent emissaries to Mahdi for an alliance against Byzantium. Mahdī sent his envoys in return but while crossing the Mediterranean, they were captured by Byzantine ships. However, the Emperor Romanus Lecapenus released them and the Fãțimid Caliph in a return gesture reduced by half the annual tribute paid to Sicily. ${ }^{73}$

The next Caliph Qā'im instructed his General Ya qū b. Isḥāq at-Tamīmī to raid the southern coast of France and the Italian coast of Genoa and $\mathrm{Ca}$ labria. ${ }^{74}$ The city of Genoa was occupied. ${ }^{75}$ Crete, Corsica, Malta and Cyprus followed suit, although only for a short while. In fact according to Ibn Khal-

\footnotetext{
70 Ms. Hamdani Coll. See Ivanow: Ismāeili Literature, pp. 32-33.

71 Canard: Fäțimids - E. I. 2.

72 I. Zub: Dhakha'ir, pp. 131-132 and many other sources in Dölger, Regesten, I, 69 (no.

73 Canard: Fätimids - E. I. 2.

74 Amari, Sicilia, Vol. II, pp. 211-212, mainly on the authority of Dhahabĩ Ta'rikh alIslām and Ibn Khal. : 'Ibar.

75 Amari, op, cit. (Arabic text) vol. I, p. 459, extract from Dhahabī's Ta'rikh. Also Maqrizi: Khị̣aṭ, II, 163.
} 578). 
dūn, ${ }^{76}$ the Fãtimids became the masters of the entire Mediterranean and their fleets operated freely throughout its length and breadth. The Byzantine emperor, on the other hand, supported the revolt of the Girgenti. ${ }^{77}$ and turned his attention to exchanging embassies with the 'Abbāsid Caliph Raḍi in 326/ 937 and $327 / 938 .^{78}$

In 335/946 when the dangerous revolt of Abū Yazīd, the Kharijite leader was brewing, a Byzantine embassy arrived, probably to apprise itself of the situation, and was welcomed by al-Manșūr ${ }^{79}$ who had just succeeded to the Caliphate. Recovering from the rebellion, Manșūr sent the celebrated Amīr Hasan b. 'Alī to Sicily as governor. His Kalbite dynasty ruled the island for the Fāțimids ${ }^{80}$ for more than a century till it was taken by the Normans.

Byzantium now wanted a long term truce with the Fāțimids. The opportunity to dictate it came when the Umayyad Caliph of Spain asked the Emperor in 344/955-6 for help against the Fãțimids. The Emperor Constantine VII proposed this truce to Mu'izz (the fourth Fãțimid Caliph) or else his troops would help the Umayyads. In retaliation Mu'izz had the Kalbite 'Ammār land troops in Italy in the next year. ${ }^{81}$ Soon after, a Byzantine ambassador arrived in $346 / 957$ with tribute and obtained a truce for five years. Caliph Mu izz in a reply to the ambassador did not accede to the latter's request to send an embassy to the Emperor, on the ground that he had no need "unless the Emperor accedes to our request." 82 Stern thinks this "request" involved the acceptance of Islam; more probably, it concerned Byzantium's help in the big undertaking of Mu'izz's career, namely the conquest of Egypt.

Some Muslim emigrants from Umayyad Spain who had established a colony in Crete raided in the Aegean Sea as far as Thessalonica. ${ }^{83}$ When thre-

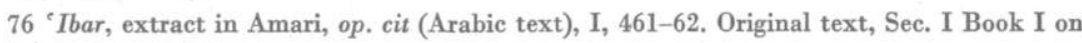
the Leadership of Fleets.

77 Art. Djirdjent in E. I. 2; Amari, op cit. II, 218 seq., Vasiliev, Byz. et Arabes II, 261.

78 I. Zub. Dhakhar' ir, pp. 60-64 (nos. 73, 74). Cf. Dölger: Regesten, I, p. 78 (nos. 632, 633).

79 Canard: Fātimids - E. I. 2.

80 I. Ath: Kämil, VIII, 354; I. Khal: 'Ibar (Cairo ed.) IV, 43.

81 an-Nu'mān: Majālis, Vol. I, reproduced in $\mathrm{Da}^{e}{ }^{\top} \mathrm{I}$ Idrīs ${ }^{\complement} U_{y}$ yn, Vol. VI, quoted in Hasan and Sharaf: al-Mu'izz, p. 39 seq. Cf. Stern: Embassy, 211.

82 The anonymous history Kitabal- ${ }^{-} U y u ̄ n$ (in yr. 346) ef. Dölger: Regesten, I. p. 83 (no. 668). Details given in Nu'mān's Majālis (the relevant passage translated in Stern, Embassy, 244-249, being Caliph Mu'izz šreply to the Byzantine ambassador).

83 Vasiliev: Byz. Empire, I, 372-374. His description is based on the eyewitness account of the priest John Cameniates. Also see K. M. Setton: On the Raids of the Moslems in the Aegean 
atened by the Byzantines, they sought the help of Caliph Mu'izz. The Fātimid navy defeated the three fleets of Byzantium, Umayyad Spain and Ikhshỉdid Egypt, thus bringing Crete under its protection. ${ }^{84}$ This was in violation of the truce that had been previously arranged. However, in $351 / 962$ Crete was surrendered to the Byzantines, probably as a deal by which Fățimid authority was recognised in Sicily and in an attempt to neutralise it while the Egyptian campaign was being planned.

At Constantinople, the new Emperor in 352/963 was the forceful Nicephoros Phocas. His mission to Caliph Muți at Baghdad in the next year was sheer insolence. His victories were listed and his intention of conquering the East was stated. ${ }^{85}$ Against the Fātimids, he resumed hostilities in Sicily and discontinued tribute. The Fațimid army and fleet inflicted two defeats on Byzantium at the Battle of Rametta and the Battle of the Straits in 354/965. The poet Ibn Hāni sang the praises of this victory. ${ }^{86}$ This resulted in the signing of a peace treaty in $356 / 967$ between the two powers ${ }^{87}$ The very next year Nicephoros sent another mission demanding the release of the Patriarch Niketas taken prisoner in Sicily. This resulted in an anti-Baghdād Pact. ${ }^{88}$

With its conquest of Egypt in 358/969, the Fāțimid State developed a new frontier with Byzantium, in Syria, and gradually reverted to peaceful commercial relationships in the Mediterranean, with Amalfi, near Naples as its window to the West. ${ }^{89}$ Syrian politics brought many complications. Besides Byzantium and the 'Abbāsids on its frontiers, there was the eternal problem of the Arab bedouin tribes (the Hilalians) influenced by the dissident Qarmatian creed and allitd to Turkish soldiers of fortune under Alptegin (Aftakin, Alaftakin, Haftakinn). Byzantium under John Tzimisces supported Alptegin an feared the Fățimid advance in Syria. ${ }^{90}$

Basil II had acceded to the Byzantine throne in 976 and was to rule until 1025, a period that saw a revival of Byzantine power and prestige abroad.

in the Ninth Centuries and their alleged occupation of Athens, American Journal of Archeology, 58 (1954) 311-319. Also A. M. Fahmy: Muslim Sea Power in the Eastern Mediterranean, Cairo, 1966, pp. 100-113; 128-138.

84. Nưmān: Majālis (MS.) II, 412, Cf. Hasan Ibrahim Hasan: al-Mu'izz, p. 46 seq.

85 Dölger, Regesten, I, p. 90 (no. 701) on the authority of Ibn Kathhir.

86 Quoted in Canard: Impérialisme, p. 187.

87 Dölger: Regesten p. 91 (no. 708) on the author. of Ibn Dinar.

88 Ibid., p. 92 (715).

89 Citarella: Amalfi, pp. 299-312.

90 I. Qal. Dhayl, pp. 11-18. 
In three missions in quick succession he settled his southern front. The first was a letter to Baghdād in $371 / 979$ protesting against 'Adud ad-Dawla's support and refuge to a rebel $;{ }^{91}$ the second was to Sa'd ad-Dawla the Hamdānid ruler of Aleppo in $376 / 988$ obligating him to a tribute to be paid according to a treaty that was signed; ${ }^{92}$ the third was to the new Fantimid Caliph al- Aziz in $377 / 987$ with lavish gifts. It was agreed that ${ }^{~}$ Aziz would be prayed for in the mosque at Constantinople as the rightful Caliph of Islam and that he would undertake the restoration of the Church of Holy Sepulchre at Jerusalem. ${ }^{93}$ These missions put the Byzantine foreign policy, as had existed for a long time, in clear perspective-they needed to cultivate Fātimid friendship and use it against their common foe, Baghdād. They also needed peace with the Hamdānids of Aleppo for the security of their frontier.

'Azĩz solved the southern Syrian problem by defeating the Qarmatians and the Turks of Alptegin. The Qarmatians retired permanently with a promise of tribute; the Hilālian tribes transplanted from Syria and settled in southern Egypt; Alptegin was brought to Cairo as prisoner but was taken into Fātimid service and put in charge of a newly formed Turkish guard. The veteran wazìr Ya qūb b. Killis was opposed to this, had Alptegin killed, and was himself removed from office, but was later reinstated. In Palestine, a Jarrāḥid governor Mufarrij b. Daghfal remained a real trouble-maker. ${ }^{94}$

When Caliph 'Azĩz visited the dying wazĩr Ibn Killiss, the latter gave him this advice: "O, Commander of the Faithful, keep peace with Byzantium, when they keep peace with you; keep the Hamdānids satisfied by constant contact (da wa and sikka, thus recognising their autonomy) but do not let al-Mufarrij b. Dagḩfal b. al-Jarrāh remain, whenever there is an opportunity to do so." 995

After Ibn Killis's death in 380/990 the advice was not heeded; fresh hostilities opened with Byzantium and continued till after the accession of Ḥākỉm. The main reason for this was the Emperor Basil's pressure on Aleppo. From now on, Aleppo was destined to remain the focal point of a triangular

91 Dölger: Regesten, I, 98 (no. 763) on the authority of Ibn al-Athỉr and Bar Habraeus.

92 Ibid., (no. 769) on the authority of Aleppan historian Kamāl: Halab.

93 Ibid., (no. 770) on the authority of I. Ath. and others.

94 I. Qal. Dhayl, pp. 19-32, I Khal, ' Ibar (in De Slane), I. 29; Maqrīzī, Itti 'ēz, pp. 249-270 (yrs. 369-380 H.).

95 I. Qal. Dhayl, pp. 32. I. J.: Muntaz̧am VIII (yr. 380 H.), I. Kh. Wafäya, II, 442; trans. IV, 365 . 
conflict between the three powers - Fãțimid, 'Abbāsid and Byzantine, till the Battle of Manzikert which itself developed from politics involving Aleppo:

The Fāṭimid governor of Damascus, Manjutakin, laid siege to Aleppo in $382 / 992$. Basil hastened to its relief and from there proceeded to Apamea, Antioch and Tripoli, but returned from there to Tarsus and Constantinople. In the meantime Byzantine vessels were cruising near Alexandria. But the return of the Emperor shows that he was not seriously intending to march on Egypt. ${ }^{96}$ In $387 / 997$, the year after 'Aziz's death there was an uprising of sailors at Tyre, fomented by Byzantium; however, the Fãtimid commander Jaysh was able to put it down after defeating a Byzantine force at Apamca. ${ }^{97}$

With the accession of Caliph Hākim, a new era of long truces with Byzantium begins. Ḥākim's administrator Barjwān approached Basil for a truce and the emperor welcomed the idea. A ten years, truce was agreed upon in $388 / 998 .^{98}$ A similar truce was also made by Basil with Ibn Marwān, the Amīr of Diyār Bekīr. ${ }^{99}$ Exactly during the years of this truce Hākim enacted many discriminatory ordinances against Christians and Jews in his realm. In $399 / 1009$ the Church of the Holy Sepulchre at Jerusalem was ordered to be demolished. ${ }^{100}$ This is considered as one of the provocations for the Crusades. However it was not viewed by Byzantium so seriously. At the most, commercial relations with Egypt were broken off by Basil in 406/1015 only temporarily. In 412/1021 shortly before Hākim's death attempts at reconciliation were made. ${ }^{101}$ Byzantine diplomacy was shrewd enough to understand that Ḥākim's many acts of discrimination were not a result of hostility but of mental aberration; that they were directed not only toward Christians but also toward Muslims, and that they were never consistent, since periods of great favour to the religious minorities alternated with periods of discrimination. It must be remembered that in $402 / 1011$, the 'Abbãsid Manifesto launched a major anti-Fāțimid propaganda campaign at the initiative of the ${ }^{e}$ Abbāsid Caliph Qādir. This was no time for hostility between the Fāṭimids and Byzantium.

With the accession of the next Caliph Zahir in 421/1021, the new Byzantine Emperor Constantine VIII signed a treaty with Egypt in $418 / 1027$ by

\footnotetext{
96 I. Qal. Dhayl, pp. 40-48, Maqrizī, Itti ${ }^{e} \bar{a} z$, pp. 275-276, 285-286.

97 I. Qal., Dhayl, pp. 49-52.

98. I. Qal. Dhayl, pp. 54-55 C. V, Dölger, Regesten, I, p. 102 (no. 788).

99 Dölger, Op. cit., p. 102 (no. 790).

100 I. Qal. Dhayl, pp. 67-8.

101. Canard: Fäțimids - E. I. 2, p. 855.
} 
which the Emperor agreed to return all prisoners, to have Zähir's name prayed for at the Mosque of Constantinople, to have the mosque itself repaired and have a muezzin appointed. In return the Caliph agreed to restore the Church of Holy Sepulchre at Jerusalem, to let the Emperor appoint the Patriarch of Jerusalem and to facilitate the return to Christianity of Christians converted by force to Islam. ${ }^{102}$

In Syria and Palestine, Byzantium ,no longer challenged Fāṭimid suzerainty over Ascalon, Tripoli, Acre, Tyre, Ramla, Jerusalem and Damascus, while the Fātimids recognised Byzantine control over Antioch. Aleppo had a nominal Fãțimid sovereignty, but was actually independent under the Mirdāsids, and was truce-bound with Byzantium.

In 427/1034 Zähir was succeeded by his 8-year old son Mustanșir as Caliph. But the power rested with the latter's Sūdāni mother Sitt al-Mulk. By $429 / 1036$ it was time for the third ten year truce. On June 13 a pact was made by Emperor Micheal V with Sitt al-Mulk. 5,000 Muslim prisoners were released, and Egypt agreed to undertake new construction at the Church of the Holy Sepulchre. ${ }^{103}$ Again after ten years and with perfect regularity the Byzantine Emperor Constantine Monomachošs mission arrived in 439/1047 with gifts for the renewal of the previous treaty. ${ }^{104}$

We have noted in the previous section that by now the Saljūq power was well established in Khurāsān and Persia, and that the Turkomans were already raiding deep into the Byzantine mainland. The Emperor had sent a mission to Tugbril Beg in 447/1050 for the release of Liparites taken prisoner in the earlier encounter with Ibrāhim Yināl in 440/1048. We have also noted Tughril's appearance at Constantinople in $443 / 1057$ demanding passage through Byzantine territory for an invasion of Egypt and the Byzantine intervention in getting the 'Abbāsid envoy to the North African Amir Mu'izz released from Egyptian imprisonment. We have further noted the Fãțimid reaction to Saljūq - Zỉrī entente which resulted in the unleashing of the Bedouin Hilälian Arab tribes over North Africa. In 446/1052, the '-Abbāsid Caliph had re-issued the Manifesto about the origin of the Fãțimids, and Maqrizĩ says this was in connection with the "Abbāsid North African policy. ${ }^{105}$ Further

102 Maqrīzĩ, Khiṭat, II, 169. Cf. Dölger: Regesten, II, p. (no. 824).

103 Bar Habraeus, Chronography, p. 196, Cf. Dölger, Regesten, II, p. 3 (no. 843).

104 I. Ath̆: Kämil, (yr. 439); Cf. Dölger, Regesten, II, p. 7 (no. 881),

105 Maqrīzī, Itti $\bar{a} \bar{z}$ (in Idris, Glances), p. 304. 
understanding of Byzantine- Fāțimid relations can only be obtained by recognizing their confrontation with the Saljūq-"Abbāsid state.

\section{Fäțimid-Saljüq Confrontation:}

To the list of sources discussed in the previous section, one extremely important Fāțimid source will now have to be added. It is the autobiography $^{106}$ of a Fāțimid dā'ĩ Mu’ayyad fi'd-Dīn asb̧-Shỉrāzĩ (387-470/997-1077). Mu'ayyad was a Daylami Persian, brought up in the Persian Isma îli tradition. He was posted at the court of the Būyid king Abū Kālījār at Shīrāz, was on good terms with his wazīr Bahrām b. Mãfanna and hostile to the local Qādī who took orders from Ibn al-Muslima, the Ra'īs ar-Ru'asa at Bagḩād. Mu'ayyad had watched the advent of the Saljūqs in Persia at close quarters and had opposed it. In 429/1037 he was forced out of Shỉrāz by pressure from Baghdād. For nearly ten years he wandered among the city-states of Syria, and we find him in Egypt by $439 / 1047$. In whatever capacity he served the Fātimid State, he remained their specialist on Syrian and eastern affairs. In $448 / 1056$ he was sent back to Syria as a roving ambassador to the various Syrian Amīs, trying to unite them in a common effort to stop Tugbril Beg taking over the 'Abbāsid State and administration. He forged links with Basāsīrī who was responsible for the Fãțimid Khuțtba at Baghdad in 450-51/ 1058, and also with Ibrāhỉm Yỉnāl who was responsible for a dangerous revolt against Tughril. He has related all these experiences in his Sïra which is rare also because it is one of the very few autobiographies in Medieval Islam. Mu'ayyad's Dïwän contains some verses relevant to our discussion, particularly to the attempt to form a Fātimid-Büyid entente to prevent the coming of the Saljūqs. For the later Būyid court we have Ibn al-Balkhī's Färsnäma (composed between $500 / 1106$ to $510 / 1116$ ).

In 435 /1043, the Būyid Amīr Abū Tāhir Jalāl ad-Dawla died and the Kḩutba was read for the next Būyid Amīr Abū Kālijār at Bagḩdād. The situation was precarious. The Caliph seemed to manage two Khuṭbas at Baghdād, a

106 Mu'ayyed: Sira, ed. Kamil Husan, Cairo, 1949. Its first detailed study was made in my $\mathrm{Ph}$. D. thesis at the London University, 1950; but this remains unpublished. Cahen had seen a Ms. of the Hamdani collection with the late Paul Kraus at the time of writing his art. on Mantzikert (1934) where he makes a brief and very general reference to the contents of it. Makdisi has used the Kamil Husayn edition in his book on Ibn Aqil (1963) and also in his article on the Mazyadids of Hilla. However, the focus of their attention is on Turco-Byzantine relations, and the Fatimid dimension of the problem has been left vague. 
Büyid one, officially and unwillingly; and a Saljūq one, unofficially and willingly. It was a matter of time before Tugḩril would arrive in Bagḩdād and oust the Būyids. Men like Ibn al-Muslima and the Qãḍi Māwardi were keeping the Saljūq interests in Baghdãd intact. At this time, the Ghuzz were active in Anatolia, Qarmisinn and Mosul. Tughril himself embarked on an extensive raid in Byzantium that took him as far as Erzerūm. This was in 446/1054. ${ }^{107}$

Before this time the Byzantine Emperor Constantine Monomachos had the Patriarch write to the Pope Leo IX in 1053, appealing for peace between the Churches. ${ }^{108}$ Such approaches were to continue later till the coming of the Crusades. At the moment, it was in the immediate context of the fear of Turkoman raids.

Tugbril's arrival at Erzerūm coincided cith a Fāțimid embassy at Constantinople. The Emperor had agreed to release 400,000 ardabs of grain to famine-stricken Egypt, but before the grain could be shipped the Emperor died. Empress Theodora, who succeeded, was so alarmed over the Turkish invasion, that she refused to ship the grain to Egypt unless Egypt agreed to a complete defensive and offensive alliance. Egypt not agreeing to this, the previous agreement was annulled. The Fātimids reacted by an attack on Byzantine Antioch but its commander Makin ad-Dawla Ibn Mulhim was taken prisoner along with a large part of his troops. However, the Fãțimid Caliph sent the Qãdī Abū ${ }^{e}$ Abd Allah al-Quḍāẽ to Constantinople with a mission of peace in 447/ 1055. But Tughril continued his pressure. He requested by letter the reading of the ${ }_{8}$ Abbāsid Caliph's Khutha at the Mosque of Constantinople, which was done. The Fāțimid envoy al-Quḍāẽ̃ was humiliated. When he reported this to Cairo, the Church of Holy Sepulchre was sacked in retaliation. ${ }^{109}$

These events show a persistent Saljūq effort to proceed against Egypt by first spoiling its relations with Byzantium and to make their long-standing alliances ineffective. Soon after Tughril declared, (in the same year) that he intended to proceed to Mecca for pilgrimage and then to the conquest of Fãțimid Syria and Egypt. ${ }^{110}$

At Baghdād things were brought to a head. It started with Ibn al-Muslima accusing publicly Basāsīrỉ, the Commander of the Turkish troops of the

107 I. J. Muntazam, VIII, pp. 117-160. for the yrs. 435-446 H. Cf. for the same years identical information in I. Ath̆: Kämil.

108 Dölger: Regesten, II, 10 (no. 911).

109 Maqrizi: Khiṭat, I, 266. Cf. Quatremère: Mémoire, II, pp. 318-19; Dölger: Regesten, II pp. 10, 12 (nos. 912, 929).

110 Ibn Muyassar, Akhbär, p. 7, Mu’ayyad: Sira, p. 95. 
Būyid Amīr al-Malik ar-Rahīm of corresponding with Egypt. Basāsīī was ousted from Baghdād at about the same time that Tughril entered it. At Raḥba, Basāsĩrĩ was contacted by the Fāțimid Dāeĩ Mu'ayyad. Mu'ayyed had come to Syria and was in touch with the Kilābĩ Thimāl b. Mirdās b. Sāliḥ, the Mirdāsid Chief of Aleppo; the Numayrĩ Ibn Waththāb at Harrān, Ibn Marwān at Diyār Bekir, the 'Uqaylī Quraysh b. Badrān at Mosul, and the Asadĩ Dubays b. Mazỉd of Ḥilla.

Tughril had entered Baghdād in 447/1055, arrested the Būyid al-Malik ar-Rahỉm, was officially acknowledged now at Baghdād by the Caliph and had brought the rulers of Tabriz, Ganja and Mosul under his suzerainty. In the meantime the Basāsīrī-Mu'ayyad combination made allies among the petty chiefs of Syria and while Tughril's troops were on leave for Navrūz, Baghdād was taken by storm and Fāțimid Khuțba read there in 449/1058. Ibn al-Muslima was killed; the Caliph was kept a prisoner.

Tughril was prevented from returning to Bagḩdād by the revolt of his half-brother Ibrähỉm Yinal who had received monies and provisions from the Fãtimids, through Mu'ayyad; at the same time Mu'ayyad had corresponded with Tughril's wazir al-Kundari in an attempt to win him over.

After dealing with Ibrāhīm at Hamadan who was taken and killed, Tughril retraced his steps towards Bagḩād and occupied it. In 451/1059 Basāsīrĩ died fihting. The Caliph was released and met Tugbril for the first time. The rest of the story is well known. (For details, see Sirra of Mu'ayyad).

From the details of the Basāsīrī incident emerge two important considerations-the Fãțimid desire to surround and crush the Abbāsid Caliphate by creating a large entente between the Arab bedouin rulers of Syria (although their attitude constantly fluctuated), and their complicity with Ibrāhỉm Yīnāl. ${ }^{111}$

At Cairo Yāzūrỉ, the Fāțimid wazīr was arrested in 449/1057 on charges of correspondence with Baghdād, and later executed. Mu'ayyad had returned to Egypt and would now hold the post of the Chief Dāe i till the end of his life (in 470/1077). (Details in Sĩra of Mu'ayyad).

Between the death of Yāzūrī and the coming of Badr al-Jamālī, that is between 449/1057 and 467/1074, Egypt was engulfed in great administrative

111 The later Ismā îiı historian, Idrīs 'Imädad-Dīn, in his 'Uyūn, VII (MS. Hamdani coll.) p. 58 states that the ultimate discomfiture of Ibrāhim Yināl was due to the differences of opinion among the ministers at the Fäțimid court which prevented Cairo from rescuing him in time. 
crises. During this period 40 wazỉrs and 42 qãdīs were changed, and famine and plague stalked the country. During these difficult days the only person in the confidence of the Caliph Mustanșir was his chief of Da'wa Mu'ayyad who relinquished his duties only two months before his death in 470/1077. In all the diplomatic exchanges of the Fãtimids with Byzantium, where Saljūqs were involved, Mu'ayyad's role must be inferred.

In 448/1056, the Caliph Qā'im had married Khadīja, Arslan Khātūn, daughter of Chaghrî Beg and niece of Tughril and the ceremony was performed by Ibn al-Muslima and attended by the Qãdī Dāmighānī and the Aqḍa'lQuḍāt Māwardī. ${ }^{112}$ In 452/1060 we find Arslān Khātūn at Tugbril's court in Rayy, not allowed to return to her husband, as the Caliph was hedging Tughril's request for the hand of his daughter in marriage to the Sulțān. Makdisi states that Tughril intended to transfer the 'Abbāsid caliphate to his own line through the offspring of this marriage. During the last years of Tughril's life his relations with the Caliph soured. Although the marriage was at last performed in $455 / 1063$ the Sulțān died childless within six months. ${ }^{113}$

The aftermath of the Fātimid attack on Baghdād was disastrous for them. We know that the mainstay of the early Fātimid state was the Berber army' and particularly the leaders of the Kutāma tribe. 'Azīz had introduced Turkish troops commanded by Alptegīn. The wazīr Ya qūb b. Killīs opposed their introduction. During Hākim's time much of the malaise was due to the BerberTurkish conflict. In the time of Caliph Mustanșir, his Südānī mother had introduced the Sūdānỉ guards. Now the conflict became triangular among these three elements. For some time Egypt had experienced difficulties due to Persistent low levels of the Nile river, and the treasury was depleted from military adventures at Bagḩād and eonstant war in Syria. A descendant of the Ḥamdānids of Mosul, Nāṣir ad-Dawla had risen to be the governor of Damascus. He kept on pressuring Aleppo, till he was taken prisoner in 451/1062 and sent to Cairo by the Mirdāsids. He was put in charge of the Turkish and Berber troops there by Mustanșir in order to suppress the uprisings of the Sūdānĩs. He succeeded in doing so in $459 / 1067$ but in turn became dictatorial. His rapacious conduct added to the great famine of 454-459/1062-1067 (called ash-shiddat al- uzma) and made things so intolerable that the Caliph himself commanding a force of local Turks defeated Nāṣir ad-Dawla in 461 /1068-9, who then operated from the Delta. It is then that Näșir ad-Dawla appealed

112 I. J. Muntazam, VIII, pp. 169-70.

113 See Makdisi: Marriage, pp. 259-275. 
to the Saljùq sulțān Alp Arslān to invade Egypt. In Egypt now there was a dual authority-that of the Caliph at Cairo and of Nāșir ad-Dawla in the Delta. ${ }^{114}$

The situation had to be corrected. There were candidates willing to come to Egypt and restore order for the Caliph. One such was the Dāei-Sulțān of Yaman 'Alī b. Muḥammad aṣ-sulayḥi who had by now built a strong state in southern Arabia. However, when he was on his way to Egypt, at the pilgrimage time at Mecca in 459/1067, he was assassinated. Much later the same role was fulfilled by the Armenian governor of 'Akka, Badr al-Jamāli.

The situation in Syria was extremely nebulous. In 455/1063 Badr alJamālī became the Fāṭimid governor at Damascus, while 'Atiyya, the Mirdāsid ruled Aleppo on behalf of the Fãtimids, but both were soon ousted. 'Atiyya was under attack from Maḥmūd and Badr had to retire to Ascalon. Damascus passed through various hands. Badr had sent an 'Alid Ibn Shūya to Damascus but was defied by its residents. The fityān of the town set up two leaders: Mismār b. Sinān of the Kalb tribe and Ḥāzim b. Nabhān b. al-Qurmați. Then the city was ruled by a brother of Haydara b. Manzu a previous governor. Tyre was autonomous under Ibn Abī 'Aqīi Tripoli under its qādī Ibn 'Ammār Abū Țālib; Ramla and the coast was controlled by Ibn Ḥamdān. Nothing remained in the hands of the Fãțimid governor Badr except Acre and Tyre. This was the situation in $462 / 1070$, just before the Battle of Manzikert. ${ }^{115}$

Before we pass on to the next section, a brief reference should be made to an interesting letter from the Byzantine Emperor Constantine X Dukas to Pope Honorius II in early $455 / 1063$. The Emperor was asking the Pope to arrange an alliance between him and the Western Roman Emperor Henry IV. He wanted the unity of the Roman world under the leadership of the Pope. He was willing to offer his son as a hostage and the imperial trcasury as a security. His desire was to liberate the Church of the Holy Sepulchre. ${ }^{116}$ This

114 These events are described in most of our sources. Maqrizi's $I t t i^{i} \bar{a} z$ (Istanbul MS) for the year 454-462 H. is full of the account of famine and ravages of Nãsir ad-Dawla; also his book Ighäthatal-Umma fî Kashf al-Ghumma devoted to the famines of Egypt has some references. (translated by Wiet under the title: Le Traté des Famines de Maqrizī, J. E. S. H. O., Vol. V (1962), pp 1-90) Cf. Quatremère: Mémoire (mainly based on Ibn al-Jawzi and Maqrizi), and Gibb and Kraus: Al-Mustanšir-E.I.1.

115 Sibț. Mir'āt in Amedroz ed. of Ibn. Qal.: Dhayl, note on p. 97.

116 Dölger, Regesten, II, p. 15 (No. 952) on the authority of Benzo, the Bishop of Alba. Dölger thinks it is genuine on the grounds of the corroborating accounts mentioned. 
is another evidence of the Byzantine desire for a crusade which had hardened by the Turkoman pressure, and would become an idee fixe after Manzikert. The reference to Jerusalem does not in anyway indicate an anti-Fāțimid design because in any case the Fațimid control of Jerusalem at the moment was dubious due to the depredations of Nāșir ad-Dawla, whose influence at Ramla near Jerusalem was strong.

Manbij, Aleppo, Manzikert.

For the events surrounding the battle of Manzikert, the sources have been analysed in detail by Cahen in his article on Manzikert (1934). He has analysed the same sources in his Syrie du Nord (1940) and in his article on the Historiography of the Saljüqs (1962). For all these titles and those that follow see the bibliographical index. Let me make some brief observations about the relative value of only the basic sources: Ibn al-Qnlānīsĩ (d. 555/1160) uses for this period an older source, the lost history of Ghars an-Ni'ma (d. 481/ 1088). But the information is sparse and as his concentration is on Damascus, these events are remote from him. On the other hand Sibț b. al-Jawzĩ (d. $654 / 1256)$ has the most detailed information, although at times the long dialogues that he reports seem to be his own reconstructions, and in these parts should not be given much reliance. His source of information is also Ghars an-Ni'ma and Hamadānī (d. 521/1127). Two other authors are close to the site of the events, namely Ibn al-Azraq al-Färīị (d. 572/1176) and Kamāl ad-Dỉn b. al-'Adīm (d. 661/1263). Fārīiỉ wrote a history of Mayyāfäriqin and Amid, a territory near Manzikert, but unfortunately he gives only a brief account, found elsewhere also. Kamāl ad-Dīn wrote a history of Aleppo, Zub$d a$, and a biographical dictionary, Bughya. He uses earlier historians of northern Syria, whose, works are lost, ${ }^{\circ}$ Azỉmĩ $(48 / / 1090$ - d. after 557/1161). For our purpose his work is the most important, because Aleppo was the storm centre of the politics that shaped the events leading to Manzikert, because he gives certain pertinent information like a Fāțimid embassy at Manbij in 461 / 1069 which is not found elsewhere, and lastly because of his accuracy in mentioning details of names, places and dates conforming to a proper sequence of events. For Byzantine sources, the works of Laurent and Charanis (see index) sould be consulted.

Tugbril had died childless. He had adopted his brother Chagbri's adopted son, Sulaymãn, and favoured him for succession. His wazīr Kundarī was committed to this. Qavurd, another son of Chagbri was in control of southern 
and eastern Persia and wanted to keep it. The younger Alp Arslān (born in 421/1030) had succeeded his father Chaghrī on the latter's death at Marw in 452/1060. Previously he had led his father's campaigns against the Ghaznawids, and recently he had supported his uncle Tugbril against Ibrāhim Yināl in 450/1058. On Tughril's death he succeeded to his domain also and was recognised by the Caliph as Sulțān in $455 / 1063$. Unlike his uncle he never set foot in Bagḩdād and ruled from Rayy with the help of his wazĩ Nizām alMulk, keeping a correct distance from the Caliptal court. Having suppressed the various contenders for Sultanate-his two brothers Sulayman and Qavurd, his grand uncle Mūsa Yabghū and his distant cousin Qutlumush, he embarked on Tughril's unfinished work-of conquering the lands of the western Caliphate across the territories of Byzantium. Wherever he went, he was preceded by Turkoman bands who opened the way for him. In 456/1064 he captured Ani and Kars. By 460/1068 he had received the submission of Georgia, and used the Shaddādids of Arrān and the 'Uqaylids of Mosul as buffer states, acknowledging his suzerainty. He captured Arjish and Manzikert from Byzantium in early $463 / 1071$ and attacked the Byzantine fortresses of Sevaveragand Edessa. Soon after he descended on Aleppo and received the submission of the Mirdāsid Maḥmūd. ${ }^{117}$

At Constantinople, the death of Constantine X Ducas in May 1067 had created a crisis of succession. The power rested with the widow Eudocia as regent for her young son Micheal, supported by Psellus and Caesar John, a brother of the late Emperor. However a military faction saw the need of a strong ruler to cope with the incursions of the Turks. First the Patriarch then the Queen were convinced. The Queen married the General Romanus Diogenes and accepted him as the Emperor in January 1068. Romanus had previously distinguished himself against the Pechenegs and now took up the struggle against the Saljūqs. He had several successes against the Turkoman bands that preceded the advent of Alp Arslān; but his major victories were the taking of Artāh near Antioch and Manbij near Aleppo, thus assuring communications between Edessa and Antioch. From Manbij the Emperor returned to Constantinople in 1071 to muster a motley force of mercenaries comprising of Greeks, Slavs, Armenians, Georgians, Pechenegs, Uzes, Alans, Varangians and Normans, while his young General Manuel Commenus guarded the eastern frontiers. ${ }^{118}$

117 See Cahen's: Manzikert and art. Alp Arslan-E.I.2 No further documentation seems necessary on an already worked subject.

118 See Ostrogorsky: Byz. Hist. pp. 303-4, and Charanis: Byz-Eleventh Century pp. 191-93. 
In Egypt, during the years 461-462/1068-69, as we have already noted, a sort of dual authority existed, that of the Caliph Mustanșir at Cairo, and of Näșir ad-Dawla b. Hamdān, a rebel, in the Delta; and the country had for a decade suffered from famine, plague and the ravages of the troops. Egyptian authority in Syria had collapsed. An invitation had been sent by Nāșir ad-Dawla to Alp Arslān to invade Egypt. Nāṣir ad-Dawla's mission to Alp Arslan was led by Abū Ja far Muḥammad b. Aḥmad al-Bukhārī known as Qāọi Ḥalab and the 'Abbāsid Kḩuṭba was read in Alexandria, Dimyāṭ and the Delta region already in $462 / 1069 .{ }^{119}$ In the next year, Nāṣir ad-Dawla sent a mission to Constantinople led by his envoy Tāj ar-Riyāsa Abū Manșūr ‘Abd Allah b. Nașr ar -Raḥabỉ, known as Ibn al-Khallāl with a gift of 40,000 dĩnārs and other precious things to the Emperor Romanus Diogenes. The Emperor, in return, also sent gifts to Nāșir ad-Dawla. Ibn Khallāl himself reported this to a contemporary writer Ibn az-Zubayr. ${ }^{120}$ The mission, was obviously an attempt by Nāṣir ad-Dawla to neutralise the Emperor, in the former's struggle against the Fāțimid Caliph.

Aleppo, ${ }^{121}$ since the time of the Hamdānid ruler, Sayf ad-Dawla had been an important base of military expeditions into Byzantium. It was coveted by the Fãțimids and later by the Saljūqs as a frontier base of the greatest importance. The Arab bedouin tribe of Kilāb had come to settle there and their chief Șālị̣ b. Mirdās became its ruler in 414/1023, thus instituting a Mirdāsid dynasty. Politics of the big powers - Fãțimid, 'Abbāsid and Byzantine was reflected in the constant changes of rulers from the same Mirdāsid family and their internal struggle. In $443 / 1051$, Aleppo's ruler Thimāl b. Sālih b. Mirdās agreed to pay an annual tribute to Constantinople and was recognised as Petrarch of the place by Byzantium. He received much money from the Fātimids in 448/1056 for helping Basāsīrī to occupy Baghdād, but on his shying away from this obligation, he was removed. From 448-454/ 1056-1062 Aleppo remained solidly under Fãtimid sovereignty, the main contenders for its control being 'Atiyya b. Sãlị̣ b. Mirdās and his nephew Mặmüd b. Nașr. On the whole 'Atiyya remained loyal to Egypt and ruled between 454-457/1062-1065. He was followed by Mạmūd, who during his long

119 Ibn Muyassar: Akhbär, pp. 19-20 and Maqrizī: Itti ${ }^{e} \bar{a} z$ (Istanbul MS) ff. 105-106. both under the year $462 \mathrm{H}$. Also Kamāl: Zubda, II, p. 19 (462 H. is stated to be the date of the mission).

120 I. Zub: Dhakha'ir, pp. 85-86 (no. 105).

121 The following details are taken from Kamāl: Zubda, I pp. 263-286, and Vol. II, pp. 11-19. Cf. Sauvaget: Halab-G. I. 2. 
rule (457-467/1065-1074) had been careful not to be too committed to Cairo lest he invite the wrath of the Saljūqus. However, he had resisted the "Abbāsid Khutba, in deference to the Shi'ite beliefs of his people in Aleppo. He had agreed to pay an annual tribute of 14,000 dinārs to Constantinople in 461 / 1068, but on wavering, the Byzantium had sent a Turkish General Sunduq against him. On this occasion Artiq, Jazr (near Aleppo), Ma arrat an-Nu'mān, Kafr Țāb, Ḥama, Ḥims and Rafniye (near Ḥims) were raided. The Aleppans resisted, but ultimately Maḥmūd made peace and sent gifts to Constantinople.

Maḥmūd now wrote to Alp Arslān for help and read the 'Abbāsid Kḥuṭba in Aleppo in 462 /1069. Bagḩdād sent a mission to him under the Naqỉ Abu'lFawāris az-Zaynabī, gave him a robe of honor and the title al-Amīr al-Ajall Ḥusām ad-Dawla. However at the approach of Alp Arslān, Maḥmūd balked, but finally submitted. From now on Aleppo permanently passed into the 'Abbāsid sphere of influence.

About the Byzantine conquest of Manbij in 1068, Kamāl ad-Dīn reports: $:^{122}$ "in $461 \mathrm{H}$. the King of Rūm marched towards Syria. He took much from the people of Manbij. Its fortress was abandoned by its people, and he took it and re-inforced it with men, provisions and arms. Then he went to ${ }^{\mathrm{C}} \mathrm{Azāz},{ }^{123}$ stayed there for a while and returned. God inflicted on him and his people draught, famine and plague. The king of Rūm said to the Qāḍi al-Quḍāẽ, the Egyptian envoy that he has suffered in one day the loss of 3,000 horses besides his troops. It is said that Manbij remained in Byzantine hands for seven years. And the king referred to is Diogenes."

We know that Qudāé ín had been sent to Constantinople as an envoy previously in $447 / 1055$ by the Fãțimid Caliph Mustanșir in an attempt to patch up the breach of truce that had occurred, because of Byzantine refusal to deliver grain to Egypt as agreed. It was a sensitive mission. His choice now is indicative of a similar sensitive situation, when Alp Arslān was at

122 Kamāl: Zubda, II, pp. 13-14.

123 North of Aleppo as noted by Sami Dahan, editor of Zubda, II, 13.

124 Muḥammad b. Salāma b. Ja far al-Quḍāei was a Shāfięi Qāụi in Egypt. He was attached to the secretariat of the Wazir Jarjarā'ī; sent to Constan-tinople on a mission in 447/1055; and on his return was employed in the secretariat of the Wazīr Yãzürī. His works are listed by Maqrizi, who thinks he is one of the earliest writers on the topography of Cairo. Qudāê's history has been an important source for later historians of Egypt, particularly Maqrīzi. His date of death is generally given as $457 / 1064$, but as we have noted in Kamāl ad-din's account he certainly was living in $461 / 1068$. See more details on him in Becker: Beiträge and Kämil Husayn: Adab Misr, pp. 40-41. 
Aleppo; the Emperor had returned to Constantinople and was in the process of equiping a large force prior to Manzikert. Our historian's mention of him in connection with the conquest of Manbij further indicates a proximity of this mission to the developments that resulted in the Battle of Manzikert. The purpose of the mission is not stated. If it was in the realm of conspiracy and secret diplomacy could it ever have been known to anyone except the parties concerned? The secrecy was necessary for two reasons; first, if its purpose had leaked to Nāṣir ad-Davla, it would immediately have been transmitted to Alp Arslān at Aleppo; second ,Romanus had certainly intended to take the Sulțān by surprise, when he proceeded to Manzikert. Although we could not be certain about it, could we not suspect, or even expect a Fãțimid-Byzantine collusion in respect of the Byzantine attack on Manzikert? However, even if it was so, the Emperor was not doing it in the interest of the Fãtimids alone. He had been elected to his office precisely for the purpose of fighting the Turkish invasion effectively. But had this invasion resulted in the occupation of Syria and Egypt, how much graver would have been the plight of Byzantium?

Again, the Fātimid Caliph at that time was in no position to render material help to Romanus. His envoy therefore would have chiefly been interested in the strategy - the choice of Armenia as the battleground, and the city of Rayy as Romanus's announced destination rather than a frontal confrontation at Aleppo. Fātimid diplomacy was interested in diverting the enemy which it could not fight. Common interests of Byzantium and the Fãttimids had evolved over a century, as we have noticed in this paper. At this particular juncture the realisation of a common danger was acute. The motivation was so strong that our inference would not be unjustrified.

Fātimid diplomacy was effective in one important respect. It was the professed ambition of the Saljūqs to occupy Egypt. Both Tughril and Alp Arslān were diverted from it. After the Battle of Manzikert this ambition remained forever frustrated. But had the Fãțimids failed, the Crusades would either have been launched two decades earlier, or would not have been launched at all. 
1. A żīmī : al-Muwașșal. al-'Aẓīmī, Muhammad b. 'Alī at-Tanūkb̧ī al-Ḥalabĩ (d. 556/1161): Kitāb al-Muwașșal ala aṣl al-Mawșil, (abridged) ed. Cl. Cahen in Journ. Asiat., 1938. (under the title: La ehronique abrégé d'al-Az̄imīi).

2. Bayhaqi: Ta'rikh. Bayhaqī (d. 470/1077): Ta'rïkh Mas üdī, 3 vols. ed. Sa'ĩd Nafĩsī, Teheran, 1940-53.

3. Bundari, Zubda. Bundari's abridgment of 'Imad ad-Din's (d. 560/ 1164): Nușrat al-Fatra. Receuil de textes rélatifs à l'histoire des Seljoukides, (4 vols. in 2), ed. Houtsma, Leiden, 1889.

4. Dhahabī: Ta'rikh. Dhahabi (d. 748/1348): Tarikh al-Islam, Ms. Br. Mus. Add. 25,700.

5. Fāriq.: Mayyāfäriqīn Ibn. al-Azraq al-Fāriqĩ (d. 572/1176): Ta'rïkh Mayyäfäriqün wa Ämid. British Mus. Ms. 5803; also quotations in Amedroz ed. of I. Qal. Dhayl, pp. 99-100.

6. Hudūd al-'Alam (ed. Minorsky) Unknown author: Hudud al-'Alam, ed. V. Minorsky, London, 1937.

7. Ḥusaynî: Zubda. al-Ḥusaynî, sadr ad-Din Abu'l-Ḥasan 'Al. b. Abi'lFawāris Nāṣir (attributed to): Zubdat at-Tawārīkh, Akḩbār Dawlat as Saljūqìya, ed. Muḥ. Iqbal, Lahore, 1933.

8. I. Ath.: Kämil. Ibn al-Athīr (d.631/1233): al-Kämil fì't-Ta'rïkh, Beirut ed., Vol. IX and X (1966).

9. I. Bal.: Färsnāma. Ibn al-Balkbī (6th 12th cent.): Färsnäma (ca. 500510 H.), London, 1921.

10. I. Funduq : Bayhaq Ibn Funduq (1100-1169) Ta'rikh Bayhaq, Chapkhana Kanun, Teheran, 1938.

11. I. Ḥam.: Tadhkira. Ibn Ḥamdūn (d. 562/1166): Tadhkira (until 553/ 1158) Cairo (Khanji) éd.

12. I. J. Muntazam. Ibn al-Jawzî (d. 597/1200): al-Muntazam fï Ta’rīkh al-mulūk wa'l-Umam, Hyderabad, 1938-41 (relevant vol. 8).

13. I. Kh .: Wafäyāt. Ibn Khallikān (d. 681/1282): Wafãyät al-A'yān, Cairo; trans. De Slane, 4 vols, Paris, 1842-71.

14. I. Qal.: Dhayl Ibn al-Qalānīsĩ (d. 555/1160): Dhayl Ta’rīkh Dimishq, ed. Amedroz, Leiden Beirut, 1908. 
15. Juzjānĩ: Tabaqät. al-Jūzjānī, Minhāj ad-Dīn (d. 650/1252): Tabaqãt-iNāṣirì.

16. Kamāl: Bughya. Kamāl ad-Dīn Ibn al-'Adīm (d. 661/1263): Bughyat aṭ-țalab fi Ta’rikh Halab. Istanbul Ms. Saray Aḥmad III no. 2925.

17. Kamāl: Zubda. Kamāl ad-Din Ibn al-'Adīm (d. 661/1263): Zubdat alHalab min ta'rỉkh Halab, ed. Sāmī Dahan, Damascus, Vol. I (1951) Vol. II (1954).

18. Kāshggharĩ : Lugha. Mahmūd Käsḩgharî: Diwān Lughat at-turc, ed. Kilisli Rifat Bey, Istanbūl, 1917.

19. Mirkb̧wand: Rawḍ. Mirkḩwand (d. 904/1498): Rawdat aș-Șafa, 5 vols., trans. by Rehatsek, ed. Arbuthnot, E. A. S., London, 1891-94.

20. Rāwandĩ: Rāhạ. Rāwandĩ: Rāhat aș-Sudūr wa Āyat as-Surūr (com. end of 6th/12th cent.), ed. Muh. Iqbal, Leiden, 1921.

21. Sibț: Mir'āt. Sibț b. al-Jawzi (Yūsuf b. Quizughlī) (d. 654/1256): Mir'āt az-Zamān fì ta'rīkh al- $A^{\mathrm{c}}$ yān. Fonds Arabe, Paris Ms. 1506; also quotations in Amedroz ed. of I. Qal.: Dhayl, pp. 100-105.

22. Zahīr: Saljūqnäma. Zahir ad - Dīn Nishāpūrī (bth/12th cent.): Saljuqnāma, ed. G. Kḩāwar, Teheran, 1953.

23. Al-Bakrī : Al-Mughrib. Al-Bakrī, Abū 'Ubayd 'Abd Allah b. 'Abd al'Azīz (d. 487/1094): Al-Mughrib fï Dhikr Bilād Ifriquiya wa'l-Maghrib, ed. De Slane, Algiers 1857. (Bagḩdād reprint).

24. I. Idhārī: Bayān. Ibn Idhāri: al-Bayan al-Mughrib, 2 vols., Leiden, 1948.

25. I. Khal.: 'Ibar. (De Slane) Ibn Khaldūn (d. 809/1406): Kitäbal- Ibar De Slane's trans. as Histoire des Berbers, 4 vols.

26. I. M. Akhbār. Ibn Muyassar (d. 677/1278): Akhbār Misr, ed. Massé, Cairo, 1919.

27. I. S. al-Ishära. Ibn aṣ-Sayrafî (d. 521/1127): al-Ishära ilä nāla'l-Wazära, ed. Mukblis, Cairo, 1924.

28. I. T. Nujüm, Ibn Taghri-bardī (d. 874/1169): an-Nujümaz-Zähira, Cairo. (relevant vol. no. 5).

29. I. Zāfir: Duwal Ibn Ẓäfir Jamāl ad-Din al-Azdī (d. 613/1216): Ta'rikh ad-Duwal. al-Munqati a, Ms. British Mus. Or. 3685.

30. I. Zub.: Dhakhä̉ir. Ibn az-Zubayr, al-Qādī ar-Rashỉd (5th/11th cent.): Kitäb adh-Dhakhä’ir wa't-Tuhaf, ed. M. Ḥamiduddin, Kuwait, 1959. 
31. Idris (Dāeĩ): 'Uyūn. Dāeĩ Idrỉs 'Imād ad-Dīn (d. 872/1467): 'Uyün al-Akhbär, Vol.' VII, Ms. Hamdani Coll.

3la. Jawhar: Sira. Abū 'Al. Manșùr al-'Aziz. al-Jawdhar., Secretary of Ustādḩ Jawdhar (d. $362 / 973)$, Copied from the latters diary: Sira, ed.

K. Husayn and Shaira, Cairo, 1954.

32. Maqrīzî: Ittiēäz. al-Maqrīzĩ (d. 845/1441): Ittie äz al-Hunafa bi Akhbär A'immati'l-Fätimiyyīn al-Khulafa, ed. Jamāl ad-Din ash-Shayyāl, Cairo (1967 ed. based on the complete Istanbul Ms. No. 3031, Library of Ahmad III, Topkapu Saray).

33. Maqrizi, Khițat al-Maqrizi (d. 845/1441): Kḥițat, 2 vols., Cairo ed.

34. Mu'ayyad: Sīra. al-Mu'ayyad fi'd-Dỉn ash-Shỉrāzĩ (d. 470/1077): asSïra, ed. M. Kāmil Ḥūsayn, Cairo, 1949.

35. Mu'ayyad: Dīwān. al-Mu'ayyad fi'd-Dīn ash-Shīrāz. (d. 470/1077): Dīwān, ed. M. Kāmil Kusayn, Cairo, 1949.

36. Nu'mān: Iftitāh. Qādī Abū Hanifa an-Nu'mān (d. 363/974): Iftitāh ad-Daiwa, (Mc. Hamdani Coll.); als ed. Wudad al-Qaḍi, Beirut, 1970.

37. Nu'mān: Majālis. Qadî-Abū Kan.fa an-Nu'mān (d. 363/974): al-Majälis wa'l-Musāyarat (Ms. Hamdani Coll).

38. Quḍāî̀: 'Uyūn. al-Quḍāề (d. after 461/1069): 'Uyūn al-Ma ärif wa funūn Akhbär al-khalä’if, Ms. no. 1779 at Dāral-kutub, Cairo.

39. Arisdaguès: Histoire. Arisdaguès de Lasdiverd: Histoire d'Armenie, trans. M. S. Prud'homme, Paris, 1864.

40. Attaliates: Historia. Attaliates, Michael: Historia, Bonn, 1853.

41. Bar Hebraeus: Chronography. Bar Hebraeus, Gregory, Chronography (events to 68531286), s. vols. trans. E. A. W. Budge, London, $193^{\circ}$.

42. Bryennius: Commentarii. Bryennius, Nicephorus: Commentarii Bonn, 1836.

43. Cedrenus-Skylitzes: Hist. Cedrenus-Skylitzes: Historicum Compendium, Vol. II, Bonn, 1839.

44. Mathew: Chronique, in Dularier E.: Chronique de Matthiey d'Edesse, Bibliotheque historique armenienne, Paris, 1858.

45. Michael Syr: Chronique. Micheal, the Syrian: Chronique, ed. and trans. J. B. Chabot, 4 vols., Paris, 1899-1910.

46. Psellus: Chronographia. Psellus, Michael: The Chronographid of Michael Psellus (Eng. trans. E. R. A. Sewter), London, 1953. 
47. Vardan, Univ. Hist. Vardan (d. 1271): Universal History, ed. Ali-an, Venice, $186^{\circ}$ (see Brosset, Georgie).

48. Amari: Sicilia. Amari, Michele: Storia dei Musalmani di Sicilia (revised by Nallino) Vol II (1935).

49. Barthold: Turkestan. Barthold: Turkestan, down to the Mongol invasion, 3rd edition, London, 1968.

50. Becker: Beitrage. Becker, C. H.: Beitrxge zur Geschichte Aegyptens, Strassbourg, 1903.

51. Bosworth: Ghaznawids. Bosworth, C. E.: The Ghaznawids, Edinburgh, 1963.

52. Brooks: Asia Minor. Brooks, E. W.: The Arabs in Asia Minor, 641-à50, Journal of Hellenic Studies, 18 (1898).

53. Brooks: Byz. and Arabs Brooks, E. W.: Byzantines and Arabs in the time of the early ${ }_{8}$ Abbäsids, English Historical Review, Pt. I (Oct. 1900), Pt. II (Jan. 1901).

54. Bross et: Georgie. Brosset, M. F.: Historie de la Georgie, St. Petersburg, 1851.

55. Bury: Emperors. Bury, J. B.: The Roman Emperors from Basil II to Isaac Komnenos, EHR, IV (1889), reprinted in Essays, ed. H. Temperley, Cambridge, 1930.

56. Cahen: Mantzikert. Cahen, Cl.: La Campagne de Mantzikert d'aprés les sources musulmanes Byzantion, 9 (1934) pp. 613-642.

57. Cahen: Syrie. Cahen, Cl.: La Syrie du Nord à l'epoque des Croisades et la principaute Franques d'Antioche, Paris, 1940.

58. Cahen: Penetration Turque. Cahen, Cl.: La première pénétration turque en Asie-Mineure (seconde moitié du XIes.), Byzantion, XVIII (1948), pp. 5-67.

59. Cahen: Malik-Nameh. Cahen, Cl.: Le Malik-Nameh et l'histoire des Origines Seljukides, Oriens, II (1949), pp. 31-65.

60. Cahen: Tribus. Cahen, Cl.: Les tribus turques d'Asie Occidentale pendant la periode seljukide,Wiener Zeitschrift für die kunde les Morgenlandes (W. Z. K. M.), Wien, 1950, Vol. 51. 51, pp. 178-187.

61. Cahen: Historiography-Seljuqids. Cahen, Cl.: The Historiography of the Seljuqid Period in Historians of the Middle East, ed. by Lewis and Holt, pp. 59-78. 
62. Cahen: Alp Arslan - E, I. 2 Cahen, Cl.: Alp Arslan, article in the Encyclopaedia of Islam (new).

62a Cahen: Çaghrī Beg-E. I. 2 Cahen, Cl.: Çaghrī Beg, art. in Encyelepaedia of Islām (new).

63. Cahen: Buwayhids - E. I.2 Cahen, Cl.: Buwayhids - article in Encylopaedia of Islam (new).

64. Cahen: Tur. Invasion. Cahen, Cl.: The Turkish Invasion: The Selchükids in Setton and Baldwin's edition of $A$ History of the Crusades, Vol. I, pp. 135-176.

65. Cahen: Turkey. Cahen, Cl.: Pre-Ottoman Turkey (English trans. by Jones-Williams). London 1968.

66. Canard: Expéditions. Canard, M.: Les expéditions des Arabes contre Constantinople dans l'histoire et dans la legende, Journal Asiatique, 208 (1926), pp. 61-121.

67. Canard: Impérialisme. Canard, M.: L'Imperialisme des Fațimides et leur propagande, Annales de l'Institut d'etudes orientales (A. I. E. O.), Faculte des Letres d'Université d'Alger, 6 (1942-1947), pp. 156-193.

68. Canard: Hamdanides. Canard, M.: Histoire de la dynastie des Hamdanides de Jazira et de Syrie, Vol. I, Paris, 1953.

69. Canard: Hamdanids - E. I.2 Canard, M.: Hamdanids - Article in the Encyclopaedia of Islam (new).

70. Canard: Hākim-E. I.2 Canard, M.: al-Häkim bi amr Allah-article in the Encyclopedia of Islam (new).

71. Canard: 'à cotể. Canard, M.: Quelques 'à-cotê' de l'histoire des relations entre Byzance et les Arabes, in Studi Orientalistici in onore di G. Levidella Vida. I (Rome, 1956), pp. 98-119.

72. Canard: Fațimids - E. I.2 Canard, M.: Fațimids - article in Encyclopaedia of Islam (newn.

73. Charanis: Origin-Crusade. Charanis, P.: Byzantium, the West, and the Origin of the First Crusade, Byzantion, XIX (1949), pp. 24-36.

74. Charanis: Byz.-Eleventh Cent. Charanis, P.: The Byzantine Empire in the Eleventh Century, in A History of the Crusades (ed. by Setton and Baldwin), Vol. I, pp. 177-219.

75. Citarella: Amalfi. Citarella, A. O.: The Relations of Amalfi with the Arab World before the Crusades in Speculum, Vol. 42 (1967), pp. 299-312. 
76. Dahan: Histories of Syria. Dahan, S.: The Origin and development of the local histories fo Syria in Historians of the Middle East, ed. by Lewis and Holt pp. 108-117.

77. Defrémery: Seldjoukides-Ismaéliens Defrémery: Histoire des Seldjoukides et des Ismaéliens etc. Journal Asiatique (J. A.), 1848.

78. Dewhurst: JRAS (1926) Dewhurst, R. P.: Abū Tammäm and Ibn Hānī, in Journal of the Royal Asiatic Society, 1926.

79. Dölger: Regesten. Dölger, F.: Regesten der kaiserunkunden des oströmischen Reichen, Parts I and II, Munich, 1924-25.

80. Erdmann: Enstehung. Erdmann, C.: Die Entstehung des Kreuzzugs gedankens, Stuttgart, 1935.

81. Gibb: Relations. Gibb, H. A. R.: Arab-Byzantine Relations under the Umayyad Caliphate, Dumbarton Oaks Papers, no. 12 (Cambridge, Mass. 1958), pp. 219-233; reproduced in his Studies on the Civilisation of Islma, pp. 47-61.

82. Gibb and Kraus: Mustanșir - E. I.1 Gibb, H. A. R. and Kraus, P.: al-Mustanșir bi llah, article in Encyclopaedia of Islam (old).

83. Grousset: Arménie. Grousset, R.: Historie de l'Arménie des origines à 1071, Paris, 1947.

84. Hamdani, A.: Sïra of al-Mu'ayyad.Hamdani, A.: The Sirra of alMu'ayyad fi'd-Dīn ash -Shĩräzĩ, unpublished $\mathrm{Ph}$. D. thesis, Univ. of London, 1950.

85. Hamdani, A.: Fātimids-Medit. Power. Hamdani, A.: Some Considerations on the Fãtimid Caliphate as a Mediterranean Power, Proceedings of the III Arabic and Islamic Studies Conference, Ravello, 1966, pub. Naples, 1967.

86. Hamdani, A.: Libya-Fațimid Period.Hamdani, A.: Some Aspects of the History of Libya during the Fätimid Period in Libya in History, Beirut, 1970, pp. 321-348.

87. Hamdani, V. A.: Sources. Hamdani, V. A.: A Critical Study of the Sources for the History of the Seljuqs of Persia and Syria (unpublished thesis, Oxford Univ., 1939).

88. Hasan: al-Mu'izz. Hasan Ibrahim Hasan and Taha Sharaf: $a l-M u^{\prime} i z z$ li dīn Allah, Cairo, 1947.

89. Houtsma: Tughril - E. I.1. Houtsma, M. Th.: Tughril Beg - article in Encyclopaedia of Islam (old). 
90. Idris: Glances Idris. H. R.: Glances sur les Zirïdes d'Ifriqüya dans le Manuscrit d'Istanbul de l'Ittiēäz al-Hunafä, Arabica, XI (1964), pp. 286-305.

91. Ivanow: Ismāeili Literature. Ivanow, W.: Ismāeilī Literature: A Bibliographical Survey, Teheran, 1963 (revised ed. of his Guide to Ismãeili Literature, London, 1933).

92. Kabir: Relations. Kabir, M.: The Relations of the Buwayhids with the Fāṭimids, Indo-Iranica, VIII (Dec. 1955), pp. 28-33.

93. Kabir: Buw. Dyn. Kabir, M.: The Buwayhid Dynasty of Baghdäd, Indo-Iranica, Vols. XI, II and XIII (1958-60).

94. Kāmil Ḥusayn: Adab Mișr. Kamil Ḥusayn M.: Fi Adab Mișr alFäṭimiyya, Cairo, 1963.

95. Kouymjian: Mxita'r. Kouymjian, D. K.: Mxita'r of Ani on the Rise of the Seljüqs, Revue, des études Arméniennes, Nouvelle Serie, VI (1969), pp. 331-353.

96. Köymen : Askeri Teșkilati. Köymen, M. A.: Alp Arslan Zamani Selçuklu Askeri Teșkilati, Ankara Univ. Basımevi, 1970.

97. Krueger: Ital. Cities. Krueger, H. C.: The Italian Cities and the Arabs before 1095, in Setton and Baldwin edition of A History of the Crussades, Vol. I, pp. 40-53.

98. Laurent: Byz. et Turcs. Laurent, J.: Byzance et les Turcs Seldjoucides dans l'Asie occidentale jusqu'en 1081, Nancy 1913.

99. Lane-Poole: Egypt. Lane-Poole, S.: History of Egypt in the Middle Ages, London, 1901.

100. Le Strange: Palestine. Le Strange, H.: Palestine under the Muslims, London, 1890.

101. - Loewe: Seljuqs. Loewe, H. M.: Seljuqs, Cambridge Medieval History, IV, pp. 299-317.

102. McCartney: Pechenegs. McCartney, C. A.: The Pechenegs in the Slavonic Review, VIII (1929-30), pp. 342-355.

103. Makdisi : Ibn Aqïl. Makdisi, G.: Ibn Aqil et la resurgence de l'Islam traditionaliste au $\mathrm{XI}_{9}$ sigcle, Damascus, 1963.

104. Makdisi: Marriage. Makdisi, G.: The Marriage of Tughril Beg International Journal of Middle East Studies (I. J. M. E. S.) I (1970), pp. 259-275. 
105. Marçais: Aghlabids - E. I.2. Marçais: Aghlabids - article in the Encyclopaedia of Islam (new).

106. Mukrimin: Turkiye Tarihi. Mukrimin Halil: Türkiye Tarihi, Selcuklu Devri, Anadolu'nun Fethi, Istanbul, 1934.

107. O'Leary: Fatimid Caliphate. O'Leary, D.: A Short History of the Fätimid Caliphate, London, 1923.

108. Ostrogorsky: Byz. Hist. Ostrogorsky, G.: History of the Byzantine State, New Jersey, 1957.

109. Pritsak: Yabju. Pritsak, O.: Der Untergang des Reiches des oguzischen Yabg̀u, Fuad Köprülü Armagani.

110. Quatremere: Mémoires-Egypte Quatremère, E.: Mémoires sur l'Egypte, 2 vols.

111. Quatremère: Mémoires-Fatimides. Quatremère, E.: Mémoires Historiques sur la dynastie des Khalifes Fãțimides in Journal Asiatique (J. A.), 1836 and 1837.

112. Sauvaget: Halab - E. I. 2. Sauvaget, J.: Halab - article in the Encyclopaedia of Islam (new).

113. Schlum: Epopée. Schlumberger, G.: L'épopée byzantine à la fin du dixigme siè̀le, Pt. III, Paris, 1895.

114. Stern: Embassy. Stern, S. M.: An Embassy of the Byzantine Emperor to the Fätimid Caliph al-Mu'izz Byzantion, Vol. 20 (1950), pp. 239-258.

115. Sümer: Turks. Sümer, F.: The Turks in Eastern Asia Minor in the Eleventh Century. Proceedings of the XIII International Congress of Byzantine Studies, Oxford, Sept. 1966, pub. London 1967, pp. 439-441.

116. Talbi: Aghlabides. Talbi, M.: L'Emirat Aghlabide, Paris, 1966.

117. Toumanoff: Background. Tuomanoff, C.: The Background to Mantzikert, Main paper XIII, Proceedings of the XIII International Congress of Byzantine Studies, (Oxford, Sept. 1966), London, 1967.

118. Vasiliev: Byz-Arabes. Vasiliev, A. A.: Byzance et les Arabes, 2 vols. (French trans. from the Russian original of 1900-02).

119. Vasiliev: Byz. Empire. Vasiliev, A. A.: History of the Vyzantine Empire, 2 vols. 1928 (reprint Madison, 1964).

120. Vasiliev: Episodes. Vasiliev, A. A.: Notes on some episodes concerning the relations between the Arabs and the Byzantine Empire from the fourth 
to the sixth century, Dumbarton Oaks Papers, 9-10 (Cambridge ,Mass. 1955-1956), pp. 306-316.

121. Vasilievsky: Patzinaks. Vasilievsky, V. G.: Byzantium and the Patzinaks, Journal of the Ministry of Public Instruction, CLXIV, 1872.

122. Wellhausen: Kämpfe. Wellhausen, J.: Die Kämpfe der Araber mit den Romäern in der zeit der Umaijiden, Nachr. der Kgl. Gessell. der Wiss., Gottingen, Phil. his. kl., 1901, p. 414 seq.

123. Wellhausen: Arab Kingdom. Wellhausen, J.: The Arab Kindgom and its Fall (English trans. by M. Weir), Khayyat reprint. Beirut, 1963.

124. Wittek: Rise. Wittek, P.: The Rise of the Ottoman Empire, London, 1938.

125. Wustenfeld: Geschichte. Wustenfeld, F.: Geschichte der FatijmdenCaliphen, Gottingen, 1881.

126. Zahid Ali: Fätimiyyīn Mișr. Zahid Ali: Ta’rỉkh Fätimiyyīn Mișr, (in Urdu), Hyderabad, 1948. 